OPEN ACCESS

Edited by:

Akio Adachi,

Kansai Medical University, Japan

Reviewed by:

Eain Anthony Murphy,

SUNY Upstate Medical University,

United States

Sarah Elizabeth Jackson,

University of Cambridge,

United Kingdom

*Correspondence:

Xiang-Yu Zhao

zhao_xy@bjmu.edu.cn

Specialty section:

This article was submitted to

Virology,

a section of the journal

Frontiers in Microbiology

Received: 30 March 2020

Accepted: 10 June 2020

Published: 14 July 2020

Citation:

Wang Y-Q and Zhao X-Y (2020)

Human Cytomegalovirus Primary Infection and Reactivation: Insights

From Virion-Carried Molecules.

Front. Microbiol. 11:1511.

doi: 10.3389/fmicb.2020.01511

\section{Human Cytomegalovirus Primary Infection and Reactivation: Insights From Virion-Carried Molecules}

\author{
Yu-Qing Wang ${ }^{1,2}$ and Xiang-Yu Zhao ${ }^{1 *}$ \\ ${ }_{1}^{1}$ Peking University People's Hospital, Peking University Institute of Hematology, National Clinical Research Center for \\ Hematologic Disease, Key Laboratory of Hematopoietic Stem Cell Transplantation, Beijing, China, ${ }^{2}$ PKU-THU Center for Life \\ Sciences, Academy for Advanced Interdisciplinary Studies, Peking University, Beijing, China
}

Human cytomegalovirus (HCMV), a ubiquitous beta-herpesvirus, is able to establish lifelong latency after initial infection. Periodical reactivation occurs after immunosuppression, remaining a major cause of death in immunocompromised patients. HCMV has to reach a structural and functional balance with the host at its earliest entry. Virion-carried mediators are considered to play pivotal roles in viral adaptation into a new cellular environment upon entry. Additionally, one clear difference between primary infection and reactivation is the idea that virion-packaged factors are already formed such that those molecules can be used swiftly by the virus. In contrast, virion-carried mediators have to be transcribed and translated; thus, they are not readily available during reactivation. Hence, understanding virion-carried molecules helps to elucidate HCMV reactivation. In this article, the impact of virion-packaged molecules on viral structure, biological behavior, and viral life cycle will be reviewed.

Keywords: HCMV, virion-carried molecules, primary infection, reactivation, tegument, envelope

\section{INTRODUCTION}

Human cytomegalovirus (HCMV), officially referred to as human herpesvirus 5 (HHV5), is one of nearly 100 known herpesviruses and is subclassified as a beta-herpesvirus. The seroprevalences vary with respect to socioeconomic background. Generally, the virus is widespread (Cannon et al., 2010), and serum positive for infection in the general population has been estimated to be $83 \%$ (Zuhair et al., 2019). Moreover, seronegativity does not show a complete correlation with negativity for HCMV DNA in $\mathrm{CD}_{4} 4^{+}$hematopoietic progenitor cells (HPCs) (Khaiboullina et al., 2004). Transmission of primary infection usually occurs via intrauterine (Boppana and Britt, 1995), breast milk (Hayes et al., 1972), and contaminations exposure routes (such as saliva or genital secretions) (Khaiboullina et al., 2004; Murata et al., 2009). Reactivation occurs from latency, the sources of which are CD34 ${ }^{+}$HPCs and $\mathrm{CD} 14^{+}$monocytes (Mendelson et al., 1996), often after blood transfusion and organ transplantation (Zhao et al., 2017). HCMV infection in healthy individuals is often mild or 
asymptomatic. By contrast, it is highly pathogenic among congenitally infected infants and immunocompromised patients, such as transplant recipients (Liu et al., 2015). Universal infection of HCMV and persistent lifelong infection suggest that HCMV primary infection has to negotiate a balance with the host. The virion-carried molecules are served as readily available mediators that facilitate viral survival. In this review, the significance of the factors packaged in the HCMV virion will be discussed.

\section{HCMV STRUCTURE}

\section{Genome}

The HCMV genome, the largest among nine human herpesviruses, is a linear double-stranded DNA containing 230 to $240 \mathrm{k}$ base pairs (Davison et al., 2003; Dolan et al., 2004; Bradley et al., 2009). The viral genome comprises two unique regions termed unique long (UL) and unique short (US), and these two domains are flanked by a pair of inversely repeated sequences, forming a genome configuration known as TRL-UL-IRL-IRS-US-TRS.

A few hurdles arise when analyzing the HCMV genome sequence and associated virology. First, the laboratory passaged strains AD169 and Towne following subsequent culture accumulate substantial deletions, especially in the UL/b' region, and compensated insertions of several repeats in the long terminal region in comparison to clinically isolated viruses such as Toledo (Cha et al., 1996). The UL/b' gene products pUL133-pUL138 are associated with latency, reactivation, and activation of the expression of certain genes in an interdependent manner with pUL97 (Revello and Gerna, 2010; Li et al., 2014). Additionally, the UL/b' region has been reported to be involved in NK cell evasion (Tomasec et al., 2005). Merlin and Toledo showed stronger ability against NK cell immunity than AD169 and Towne (Tomasec et al., 2005). In vitro analysis demonstrated that HCMV strains that harbor UL/b' were more sensitive to growth defects mediated by maribavir, a pharmacological pUL97 inhibitor (Wang et al., 2013). Together, high-passage strains represent a different biological manner than a wild-type virus. Moreover, the laboratory adaptation behavior differs in different HCMV strains. For example, approximately 13 and $15-\mathrm{kbp}$ sequences in the UL/b' region were deleted in Towne and AD169, respectively, compared with Toledo (Cha et al., 1996). Second, although the HCMV genome can be cloned and maintained in bacterial artificial chromosomes (BACs), mutations can occur before BAC cloning (Stanton et al., 2010). The Merlin BAC revealed that this low passage strain contains RL13 and UL128 mutations, and repair of these mutations led to impaired replication in fibroblasts (Stanton et al., 2010). The RL13 (Stanton et al., 2010) and UL128 (Ryckman et al., 2008) genes encode virion glycoproteins. Some patients present a switch in the HCMV population during the course of disease, and the dominantly altered genotypes encompass genes encoding immunomodulatory mediators and glycoproteins (Hage et al., 2017). Those genes may be associated with the pathogenesis of HCMV-caused disease (Hage et al., 2017). In vitro studies using viruses harboring mutations in such genes may provide misleading results regarding the natural behavior of clinically important HCMV. Third, without culture, contamination of cellular DNA that is difficult to eliminate from sequencing causes low viral sequence reads in next generation sequencing. Finally, regardless of immune status, the majority of patients and carriers are infected with mixed HCMV strains (Novak et al., 2008; Ross et al., 2011; Jiang et al., 2017). It has been reported that mixed infection with more than one HCMV strain is associated with severe clinical outcomes such as an increased viral load (Manuel et al., 2009) and progression to CMV disease (Coaquette et al., 2004). Although some degrees of genome instability have appeared in HCMV in vitro, a genome reference is still needed. The Merlin strain is a low passage strain and is characterized by relative genomic integrity, allowing to more accurately reflect the wild-type clinical isolates, despite some minor changes, for example, the single-nucleotide substitution in the RL13 and UL128 gene (Akter et al., 2003; Dolan et al., 2004; Sijmons et al., 2014; Wilkinson et al., 2015).

\section{Capsid (Table 1)}

The viral capsid provides a layer enclosing the genome. It is an icosahedral structure with a triangulation number $\mathrm{T}$ of 16 , containing 60 asymmetric units (Chen et al., 1999). Sixteen major capsid proteins (MCPs), 16 smallest capsid proteins (SCPs), 5 triplexes ( $\mathrm{Ta}, \mathrm{Tb}, \mathrm{Tc}, \mathrm{Td}$, and $\mathrm{Te}$ ), and $1 / 3 \mathrm{Tfs}$ exist in each unit. Five or six MCPs form a penton or hexon, with the latter subdivided into $\mathrm{P}$ (peripentonal), $\mathrm{C}$ (center), and $\mathrm{E}$ (edge) hexons as a result of different positions. Near the upper domain of MCP is the SCP. Triplexes are heterotrimers that are composed of Tri1, Tri2A, and Tri2B (Yu et al., 2017). The HCMV genome size is approximately 50\% longer than the herpes simplex virus type 1 (HSV-1) genome. The diameter of HSV-1 and HCMV capsid is approximately 125 and $130 \mathrm{~nm}$, respectively (Butcher et al., 1998). The capsid volume of HCMV is slightly larger (about 17\%) than HSV-1 (Bhella et al., 2000). The significant increase in HCMV genome size does not correlate with the slightly larger capsid volume (Bhella et al., 2000). Hence, the HCMV genome is tightly packaged within the capsid shell and protected by the capsid. This pressurized packaging of the genome is a reasonable strategy for the nucleocapsid to deliver the viral genome into the nucleus by leveraging the internal pressure within the capsid (Yu et al., 2017; Brandariz-Nuñez et al., 2019).

TABLE 1 | HCMV capsid proteins.

\begin{tabular}{|c|c|c|c|c|}
\hline Protein & $\begin{array}{l}\text { Mapped } \\
\text { gene }\end{array}$ & Kinetics & Function & References \\
\hline $\begin{array}{l}\text { Major capsid } \\
\text { protein }\end{array}$ & UL86 & Late & $\begin{array}{l}\text { Component of } \\
\text { capsid }\end{array}$ & $\begin{array}{l}\text { Chen et al., 1999; } \\
\text { Casavant et al., } \\
\text { 2006; Yu et al., } 2017\end{array}$ \\
\hline $\begin{array}{l}\text { Smallest capsid } \\
\text { protein }\end{array}$ & $\begin{array}{l}\text { UL48/ } \\
\text { UL49 }\end{array}$ & Late & $\begin{array}{l}\text { Component of } \\
\text { capsid }\end{array}$ & Gibson et al., 1996b \\
\hline $\begin{array}{l}\text { Tri1 (minor capsid } \\
\text { binding protein) }\end{array}$ & UL46? & Late & $\begin{array}{l}\text { Component of } \\
\text { triplex on capsid }\end{array}$ & Gibson et al., 1996a \\
\hline $\begin{array}{l}\text { Tri2 (minor capsid } \\
\text { protein) }\end{array}$ & UL85 & Late & $\begin{array}{l}\text { Component of } \\
\text { triplex on capsid }\end{array}$ & Gibson et al., 1996a \\
\hline
\end{tabular}




\section{Tegument (Table 2)}

Tegument is a link layer between the nucleocapsid and outer envelope, largely composed of diverse proteins that appear unlikely to form a definitive structure. The amorphous layer may contain some RNAs (Bresnahan et al., 2000; Greijer et al., 2000; Terhune et al., 2004). Although we were intrigued about the biological significance of RNA package in-between the envelope and capsid, the mechanisms underlying how the RNA is enclosed and how they interact with other elements remains largely unexamined. The tegument components are directly delivered into host cytoplasm, allowing the newly infected virus to adapt to the new cellular environment. In contrast, tegument proteins are not readily utilized by reactivated virus, indicating a difference in primary infection and reactivation. Thus, some tegument proteins that play roles in initial infection are true late proteins, which are not expressed at the early phase of the reactivated virus life cycle and are not supposed to assume responsibilities in primary infection. The diverse effects of tegument proteins on HCMV biology (Table 2) will dominate the following discussions.

\section{DNA Replication}

Human cytomegalovirus initiates lytic infection by expression of genes in a flow cascade; immediate-early (IE) phase prior to early gene expression and finally late genes are expressed to facilitate virion assemble and release (Weekes et al., 2014). DNA amplification occurs after early gene expression and before late gene expression. In vitro DNA replication usually initiates at 24 to $72 \mathrm{~h}$ post infection. OriLyt, adjacent to UL57, occupies a gene region of $2 \mathrm{~kb}$ where HCMV DNA replication commences, and there is a region that can regulate both UL57 transcription and oriLyt activation (Kiehl et al., 2003). Nuclear domain 10 (ND10) is the location for the deposition of viral DNA (Ishov and Maul, 1996), which will be discussed later in the section Roles of pp71 in primary infection and reactivation. Replicationassociated proteins are recruited to the site around the DNA replication compartment that is derived from budding of peripheral ND10 (Ahn et al., 1999). Six proteins of the replication machinery conserved in members of herpesviridae include pUL54 (DNA polymerase), pUL44 (DNA polymerase processivity factor), pUL57 (single-stranded DNA binding protein), pUL70 (primase), pUL102 (primase-associated factor), and pUL105 (helicase).

An association network is constructed in which pUL44 communicates with a series of proteins to orchestrate viral DNA replication such as cellular nucleolin, viral pUL114, and TRS1 (Strang et al., 2010a,b). UL112-113 gene products p43 and p84 may play a role in the recruitment of pUL44 (Schommartz et al., 2017). HCMV UL79, UL87, and UL95 are expressed early and recruited into the pre-replication complex with pUL44 (Isomura et al., 2011; Perng et al., 2011b). pUL44, a HCMV DNA polymerase processivity factor that is capable of tethering the catalytic subunit pUL54 onto DNA to allow continuous elongation of the DNA strand, binds to DNA and pUL54 at two sites located within the N-terminal 309 residues of the UL44 amino acid sequence
(Weiland et al., 1994; Loregian et al., 2003). Dimerization of pUL44 is critical for its function, and disruption of dimer formation blocks viral progeny production (Sinigalia et al., 2008). The nuclear localization signal (NLS) of pUL44 directs its translocation to the nucleus immediately after dimerization (Alvisi et al., 2011). Cellular protein kinase triggers phosphorylation at several lysine residues upstream of NLS in the C-terminal domain of pUL44. Phosphorylation promotes pUL44 nuclear transport, whereas another phosphorylation site, T427, inhibits nuclear targeting once phosphorylated (Alvisi et al., 2011).

An enzyme called ubc9 mediates pUL44 SUMOylation in which pUL44 is covalently conjugated to a small ubiquitinrelated modifier (SUMO) molecule in the presence of DNA, and overexpression of SUMO-1 results in increased viral production (Sinigalia et al., 2012), although the effects of sumoylated pUL44 on replication remain unexamined. The peak amounts of sumoylated pUL44 were detected in the late phase (Sinigalia et al., 2012). Moreover, three transcription start sites of UL44 were identified, with the proximal and distal promoter being activated in early infection. The middle one initiates UL44 expression in late infection (Leach and Mocarski, 1989; Isomura et al., 2008). Additional roles of both pUL44 and sumoylated pUL44 are indicated but remain unidentified other than replication (Isomura et al., 2008; Sinigalia et al., 2012). pUL44 also shows direct interactions with SWI/SNF, a chromatin remodeling complex. The formation of replication and transcription complexes prior to DNA packaging into the capsid is facilitated by chromatin remodeling processes (Ranneberg-Nilsen et al., 2012).

UL54 is a prototypical early gene that encodes DNA polymerase catalytic enzyme, which is undoubtedly one of the most important proteins during the viral lytic cycle. pUL54 contains different domains that confer it polymerase, $3^{\prime}$ to $5^{\prime}$ exonuclease, as well as ribonuclease $\mathrm{H}$ activities (Zarrouk et al., 2017). IR1, an 18-bp gene region, and activating transcription factor (ATF)-1, a transcription factor, contribute to the activation of UL54 gene expression at early and late times of infection, respectively, possibly via interactions with other host and viral proteins (Kerry et al., 1994, 1997).

In addition to those six core replication proteins, IE2, UL36-38, and UL84 proteins were thought to be necessary for OriLyt-dependent DNA replication (Sarisky and Hayward, 1996). However, UL36-38 gene products were demonstrated to be unnecessary thereafter, at least in telomerase-immobilized fibroblasts (Xu et al., 2004). pUL84 interacts with IE2 (Spector and Tevethia, 1994), resulting in transdominant inhibition of IE2, decreased early gene expression, and thus reduced DNA replication (Gebert et al., 1997). Xu et al. (2004) then reported that an active promotor within oriLyt was repressed by IE2, and this negative effect was rescued by pUL84. pUL84 has also been shown to directly interact with transcriptional binding sites within oriLyt (Kagele et al., 2009). Moreover, pUL84 associates with pUL44 and nucleolin, and colocalizes with the proteins in the replication compartments at early times of infection (Bender et al., 2014). Posttranslational phosphorylation was also observed when pUL84 interacted with cellular casein kinase 2, 


\begin{tabular}{|c|c|c|c|c|}
\hline Protein & Mapped gene & Kinetics & Function(s) & References \\
\hline pUL23 & UL23 & Early late & > Reduces the STAT-mediated INF $\gamma$ responses & Adair et al., 2002; Feng et al., 2018 \\
\hline pUL24 & UL24 & Early late and true late & $>$ Interacts with other viral proteins & Adair et al., 2002; To et al., 2011 \\
\hline pUL25 & UL25 & True late & $\begin{array}{l}\text { Co-localizes with ppUL99 in the perinuclear regions within cytoplasm } \\
\text { > Prevents Pul26 from degradation } \\
\text { > Interacts with viral proteins and behaves like a helper-a hub. }\end{array}$ & $\begin{array}{l}\text { Battista et al., 1999; Zimmermann } \\
\text { et al., } 2018\end{array}$ \\
\hline pUL26 & UL26 & Early late & $\begin{array}{l}\text { - Be a transcriptional activator of major immediate early enhancer-promoter } \\
\text { - Participate in phosphorylation and stabilization of pp28 } \\
\text { - Limits ISGylation of interferon-stimulated gene } 15 \text { (ISG15) } \\
\text { > Blocks NF-kB }\end{array}$ & $\begin{array}{l}\text { Stamminger et al., 2002; Lorz et al. } \\
\text { 2006; Munger et al., 2006; Kim } \\
\text { Y. J. et al., 2016; Zimmermann } \\
\text { et al., } 2018\end{array}$ \\
\hline pp150 & UL32 & Late & $\begin{array}{l}\text { - Highly immunogenic and pp150 antigen can be detected by ELISA } \\
\text { Interact with capsomeres and triplex on capsid and directs translocation of nucleocapsid for further } \\
\text { envelopment } \\
\text { D Be involved in nuclear targeting, organization of assembly compartment, tegumentation and virion egress } \\
\text { during late infection } \\
>\text { Restricts viral IE gene expression }\end{array}$ & $\begin{array}{l}\text { AuCoin et al., 2006; Indran et al., } \\
\text { 2010; Tandon and Mocarski, 2011; } \\
\text { Bogdanow et al., 2013; Xi et al., } \\
\text { 2017; Yu et al., } 2017\end{array}$ \\
\hline ppUL35 & UL35 & Predominantly late & $\begin{array}{l}\text { - Facilitates a proper recycling, transportation and localization of gB } \\
\text { Cooperates with pp71 to activate viral gene expression }\end{array}$ & $\begin{array}{l}\text { Liu and Biegalke, 2002; Salsman } \\
\text { et al., 2011; Maschkowitz et al., } \\
2018\end{array}$ \\
\hline pUL36 & UL36 & Immediate-early & > Inhibits caspase-8 activation and thus apoptosis & $\begin{array}{l}\text { Skaletskaya et al., 2001; Yao et al., } \\
2004\end{array}$ \\
\hline pUL38 & UL38 & Early and late & $\begin{array}{l}\text { Modulates cellular metabolism } \\
\text { > Prevents premature cell death by protecting lysosome integrity, relieving endoplasmic reticulum } \\
\text { (ER)-mediated apoptosis } \\
>\text { Accumulates translational factors by regulating poly(A) binding protein (PABA) }\end{array}$ & $\begin{array}{l}\text { Terhune et al., 2007; Xuan et al., } \\
\text { 2009; Qian et al., 2011; McKinney } \\
\text { et al., 2012; Sun et al., 2018; } \\
\text { Rodríguez-Sánchez et al., } 2019\end{array}$ \\
\hline pUL43 & UL43 & Late & $>$ Localizes in perinuclear region in cytoplasm & Adair et al., 2002 \\
\hline $\begin{array}{l}\text { HCMV DNA } \\
\text { polymerase } \\
\text { processivity factor }\end{array}$ & UL44 & $\begin{array}{l}\text { Early and late } \\
\text { (sumoylated pUL44 } \\
\text { was detected at late } \\
\text { phase) }\end{array}$ & $\begin{array}{l}\text { Tethers the catalytic subunit pUL54 onto DNA } \\
\text { C Communicates a series of proteins such as cellular nucleolin and viral pUL114 to ensue replication } \\
\text { Acts concomitantly with IE86 to block p53 activity and thus overcomes cell cycle arrest and apoptosis } \\
\text { - Binds to interferon regulatory factor } 3 \text { (IRF3), disassociates IRF3 with NK-kB and prevents subsequent } \\
\text { activation of anti-viral genes }\end{array}$ & $\begin{array}{l}\text { Weiland et al., 1994; Loregian et al., } \\
\text { 2003; Strang et al., 2010a; Kwon } \\
\text { et al., 2012; Sinigalia et al., 2012; } \\
\text { Fu et al., } 2019\end{array}$ \\
\hline $\begin{array}{l}\text { Inactive homolog of the } \\
\text { large subunit of } \\
\text { ribonucleotide } \\
\text { reductase }\end{array}$ & UL45 & Early & $\begin{array}{l}\text { C Catalyzes the dNTP synthesis } \\
\text { > Inhibits RIP1-mediated NF-kB activation }\end{array}$ & $\begin{array}{l}\text { Patrone et al., 2003; Kwon et al., } \\
2017\end{array}$ \\
\hline pUL47 & UL47 & Late & $\begin{array}{l}\text { - Regulates tegument assembly } \\
\text { - Binds to pUL48 binding protein, which is required to deubiquitylating activity of pIL } 48\end{array}$ & $\begin{array}{l}\text { Hyun et al., 1999; Tullman et al., } \\
\text { 2014; Cappadona et al., } 2015\end{array}$ \\
\hline pUL48 & UL48 & Late & $\begin{array}{l}\text { Deubiquitinating activity } \\
\text { Cooperates with pUL47 to promote disassembly of nucleocapsid and enhance the release of viral DNA } \\
\text { from capsid } \\
\text { > Guides pUL47 translocation from nucleus to cytoplasm }\end{array}$ & $\begin{array}{l}\text { Bechtel and Shenk, 2002; } \\
\text { Cappadona et al., 2015; Kim Y. E. } \\
\text { et al., 2016; Kwon et al., } 2017\end{array}$ \\
\hline pUL50 & UL50 & Late & $\begin{array}{l}\text { Form the nuclear egress complex } \\
\text { > pUL50 may have a role in maintaining HCMV genome during latency }\end{array}$ & $\begin{array}{l}\text { Dal Monte et al., 2002; Rossetto } \\
\text { et al., 2013; Lye et al., } 2015\end{array}$ \\
\hline pUL53 & UL53 & & & \\
\hline $\begin{array}{l}\text { DNA polymerase } \\
\text { catalytic enzyme }\end{array}$ & UL54 & Early & $\begin{array}{l}\text { - Have polymerase activity, } 3^{\prime} \text { to } 5^{\prime} \text { exonuclease activity as well as ribonuclease } \mathrm{H} \text { activity } \\
>\text { Target of antiviral drugs (e.g., ganciclovir) }\end{array}$ & Zarrouk et al., 2017 \\
\hline
\end{tabular}

(ER)-mediated apoptosis

.

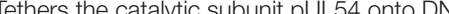

Acts concomitantly with IE86 to block p53 activity and thus overcomes cell cycle arrest and apoptosis

activation of anti-viral genes

> Catalyzes the dNTP synthesis

$>$ Regulates tegument assembly

$>$ Binds to pUL48 binding protein, which is required to deubiquitylating activity of plL48

2014: Cappadona et al. 2015

Form the nuclear egress complex

- Have polymerase activity, $3^{\prime}$ to $5^{\prime}$ exonuclease activity as well as ribonuclease $\mathrm{H}$ activity 


\begin{tabular}{|c|c|c|c|c|}
\hline Protein & Mapped gene & Kinetics & Function(s) & References \\
\hline $\begin{array}{l}\text { Single-stranded } \\
\text { DNA binding protein }\end{array}$ & UL57 & Early & > Cooperates with other replication initiation proteins to promote DNA synthesis & Anders, 1990 \\
\hline pUL69 & UL69 & Immediate-early & $\begin{array}{l}\text { Transactivate certain genes, mediate mRNA nuclear export } \\
\text { - Binds to UAP56 and URH49, and enhances the nucleocytoplasmic shutting activity } \\
\text { > Induces G1 block of host cell cycle }\end{array}$ & $\begin{array}{l}\text { Winkler et al., 1994; Hayashi et al., } \\
\text { 2000; Zielke et al., 2011; Tunnicliffe } \\
\text { et al., } 2018\end{array}$ \\
\hline pUL71 & UL71 & Early & > Contributes to secondary envelopment & $\begin{array}{l}\text { Schauflinger et al., 2011; Dietz et al., } \\
2018\end{array}$ \\
\hline pUL72 & UL72 & Late & > Be a homolog of dUTPase (inactive?) & Caposio et al., 2004; Gopal et al., 2018 \\
\hline pUL76 & UL76 & Immediate-early, late & $\begin{array}{l}\text { > Regulates UL77 gene expression } \\
\text { > Modulates gene expression (repress viral replication) } \\
\text { > Activates DNA damage response }\end{array}$ & $\begin{array}{l}\text { Wang et al., 2004; Isomura et al., 2010; } \\
\text { Costa et al., } 2013\end{array}$ \\
\hline pUL77 & UL77 & Early late & $>$ Binds to dsDNA and terminase subunits & $\begin{array}{l}\text { Meissner et al., 2011; Köppen-Rung } \\
\text { et al., } 2016\end{array}$ \\
\hline pUL79 & UL79 & Early late & $>$ Promotes the accumulation of late viral transcripts & Perng et al., 2011a \\
\hline pp71 & UL82 & Immediate-early & $\begin{array}{l}\text { Degrades Daxx } \\
\text { - Transactivation MIE gene } \\
\text { - Degrades Rb at the onset of Iytic infection, promotes cell progression and inhibits apoptosis } \\
\text { - Binds to STING and impedes subsequent activation of TBK1 and IRF3, a method against } \\
\text { innate immunity } \\
\text { > Circumvent surface MHC-I expression }\end{array}$ & $\begin{array}{l}\text { Kalejta and Shenk, 2003; Saffert and } \\
\text { Kalejta, 2006; Trgovcich et al., 2006; } \\
\text { Torres and Tang, 2014; Fu et al., 2017 }\end{array}$ \\
\hline pp65 & UL83 & Early late & $\begin{array}{l}\text { Binds to cGAS and IFI16 and interferes with innate immunity } \\
\text { - Mitigate IL-1 } \beta \text { via disrupting NF-kB signaling pathway } \\
\text { - Highly immunogenic and elicits adaptive immunity } \\
\text { > May regulates cell cycle } \\
\text { > Used in the pp65 antigenemia test }\end{array}$ & $\begin{array}{l}\text { Chevillotte et al., 2009; Cui et al., 2009; } \\
\text { Arcangeletti et al., 2011; Tandon and } \\
\text { Mocarski, 2011; Li et al., 2013; Biolatti } \\
\text { et al., 2018a,b }\end{array}$ \\
\hline pUL84 & UL84 & $\begin{array}{l}\text { Early protein synthesized at } \\
\text { late time (Spector and } \\
\text { Tevethia, 1994) }\end{array}$ & $\begin{array}{l}\text { - Associates with pUL44 and nucleoli in the replication compartments } \\
\text { Involved in initiation of viral replication } \\
\text { - Be a transdominant inhibitor of IE2-p86 during gene expression } \\
\text { - Facilitates localization of IRS1 mRNA }\end{array}$ & $\begin{array}{l}\text { Gebert et al., 1997; Colletti et al., 2005; } \\
\text { Gao et al., 2010; Bender et al., } 2014\end{array}$ \\
\hline pUL93 & UL93 & Early and late & $>$ Required for DNA cleavage packaging & $\begin{array}{l}\text { Wing and Huang, 1995; DeRussy and } \\
\text { Tandon, 2015; Borst et al., } 2016\end{array}$ \\
\hline pUL94 & UL94 & True late & > Acts as a nucleocytoplasmic shuttling protein and allows correct localization of pUL99 in vAC & $\begin{array}{l}\text { Phillips and Bresnahan, 2012; Phillips } \\
\text { et al., } 2012\end{array}$ \\
\hline pUL96 & UL96 & Early & Assists pp150 to co-stabilize nucleocapsids & Tandon and Mocarski, 2011 \\
\hline pUL97 & UL97 & Early late & $\begin{array}{l}\text { - Kinase activity (such as phosphorylating (i) antiviral prodrugs, (ii) pUL69 to contributes to the } \\
\text { viral mRNA export), (iii) Rb proteins to regulate cell cycle, (iv) nuclear lamina to promote egress } \\
\text { Organizes assembly site } \\
\text { > Activate gene expression }\end{array}$ & $\begin{array}{l}\text { Michel et al., 1996; Azzeh et al., 2006; } \\
\text { Feichtinger et al., 2011; Li et al., 2014; } \\
\text { Sharma et al., 2014; Iwahori and } \\
\text { Kalejta, } 2017\end{array}$ \\
\hline pp28 & UL99 & Late & $>$ Involved in envelope assembly & $\begin{array}{l}\text { Silva et al., 2003; Chevillotte et al., } \\
2009\end{array}$ \\
\hline pUL103 & UL103 & Late & $>$ Enhances development of cVAC & Lyons et al., 1994; Das et al., 2014 \\
\hline $\mathrm{pIRS1/pTRS1}$ & IRS1/TRS1 & Early late & $\begin{array}{l}\text { Inactivates RNA-dependent protein kinase R (PKR) } \\
\text { - Interacts with pUL44 } \\
\text { > Binds to autophagic proteins and inhibits the antophage } \\
\text { > Promotes expression of the replication genes }\end{array}$ & $\begin{array}{l}\text { Iskenderian et al., 1996; Marshall et al., } \\
\text { 2009; Strang et al., 2010b; Ziehr et al., } \\
2016\end{array}$ \\
\hline pUS22 & US22 & Early late & >Immunogenic and antigenic, and can exert humoral responses & $\begin{array}{l}\text { Dal Monte et al., 1998; Adair et al., } \\
2002\end{array}$ \\
\hline pUS24 & US24 & Immediate-early & $>$ Activate viral gene expression & Feng et al., 2006 \\
\hline
\end{tabular}

Single-stranded

> Induces G1 block of host cell cycle
- Contributes to secondary envelopm

$>$ Be a homolog of dUTPase (inactive?)

- Regulates UL77 gene expression

Binds to dsDNA and terminase subunits

Promotes the accumulation of late viral transcripts

Degrades Daxx

innate immunity

$>$ Binds to cGAS and IFI16 and interferes with innate immunity

$>$ Mitigate IL-1 $\beta$ via disrupting NF-KB signaling pathway

> May regulates cell cycle

- Used in the pp65 antigenemia test

Associates with pUL44 and nucleoli in the replication compartments

$>$ Involved in initiation of viral replication

$>$ Facilitates localization of IRS1 mRNA

$>$ Required for DNA cleavage packaging

\section{Assists pp150 to co-stabilize nucleocapsids}

$>$ Kinase activity (such as phosphorylating (i) antiviral prodrugs, (ii) pUL69 to contributes to the

$>$ Organizes assembly site

- Activate gene expression

in envelope assembly

Enhances development of cVAC

Interacts with pUL44

Binds to autophagic proteins and inhibits the antophage

Immunogenic and antigenic, and can exert humoral responses

Activate viral gene expression 
and this association was required for DNA amplification (Gao and Pari, 2009). Together, pUL84 and IE2 are essential for oriLytdependent DNA replication.

UL45 gene encodes an inactive homolog of the large subunit of ribonucleotide reductase (RR) that catalyzes the reaction of dNTP synthesis (Patrone et al., 2003). dNTP is essential for DNA replication, but whether the deletion of UL45 causes viral growth defects is still controversial. The virus may develop other strategies to synthesize dNTP (Hahn et al., 2002; Patrone et al., 2003).

\section{Protein Expression}

pUL69 is a member of the infected cell protein 27 (ICP27) family, and it contains a conserved folded domain termed ICP27 homology domain (IHD) that is required for mRNA nuclear export (Winkler et al., 1994). Although pUL69 is able to bind to RNA, RNA binding is not critical for unspliced RNA export (Toth et al., 2006). Interactions with DEXD/H-box RNA helicases UAP56 and URH49 are essential for pUL69mediated mRNA export (Lischka et al., 2006). pUL69 can be phosphorylated by cyclin-dependent kinase (CDK)-9 and pUL97 (Graf et al., 2016). The accurate nuclear localization is attributed to the phosphorylation of pUL69 (Graf et al., 2016). Inhibition of CDK activity leads to the blockade of mRNA export (Rechter et al., 2009).

Unlike most viruses that prevent cellular protein synthesis, cellular translation proceeds in HCMV-infected cells. Therefore, HCMV usurps translational factors from the host. pUL38 recruits and accumulates translational factors by regulating poly(A) binding protein (PABA), a protein that enhances the assembly of eukaryotic translation initiation factor $4 \mathrm{~F}$ (elF4F) (McKinney et al., 2012). pUL69 promotes translation by interacting with $4 \mathrm{EBP} 1$, preventing $4 \mathrm{EBP} 1$ binding to cap-binding complex, and thus relieving negative effects of 4EBP1 (Aoyagi et al., 2010). RNA-dependent protein kinase R (PKR) recognizes viral dsRNA, and PKR is dimerized and autophosphorylated to be activated upon engagement. The active form of PKR phosphorylates eukaryotic initiation factor $2 \alpha$ (eIF2 $\alpha$ ), which inhibits its function in the initiation of translation. Therefore, PKR serves as an additional defense mechanism that reduces viral synthesis. HCMV counteracts this translation repression effect by expressing pTRS1 and PIRS1 that bind to PKR followed by PKR inactivation (Ziehr et al., 2016).

\section{Nuclear Egress}

Nuclear egress is a process of transporting capsid containing newly synthesized and packaged viral genome out of the nucleus. HCMV wraps its genome into capsid to form the nucleocapsid, and insertion of viral genome into procapsid requires terminases (pUL56 and pUL89) that cleave two genomes in a concatemer. UL77 encodes a capsid-associated structural protein that can bind to dsDNA and terminase subunits (Meissner et al., 2011; Köppen-Rung et al., 2016), and it has been demonstrated that pUL77 is necessary for viral DNA cleavage and packaging (DeRussy and Tandon, 2015; Borst et al., 2016). pUL76 regulates the expression of UL77, but whether pUL76 has effects on nucleocapsid assembly is not known (Isomura et al., 2010). It has been shown that pUL93 and portal protein pUL104 also participate in DNA package (Köppen-Rung et al., 2016).

Nuclear egress complex (NEC), a heterodimer that consists of pUL50 and pUL53, transits nucleocapsid from the nucleus to the cytoplasm (Lye et al., 2015). Restriction of UL53 gene expression and abnormal localization of pUL50 block nuclear egress in p53KO cells (Kuan et al., 2016). NEC recruits pUL97, a protein kinase, to the nuclear rim where pUL50, pUL53, and pUL97 colocalize (Sharma et al., 2014). Lamin A/C, the components of the nuclear lamina, are phosphorylated by pUL97, which are then disrupted to allow the escape of the nucleocapsid from the inner nuclear membrane (Azzeh et al., 2006; Sharma et al., 2014, 2015). Deletion of immunoglobulin heavy chain binding protein (BiP), an ER chaperone, gives rise to abnormal lamin phosphorylation at late time, implying that $\mathrm{BiP}$ is also involved in nuclear egress (Buchkovich et al., 2010). The nucleocapsid budding across the inner nuclear membrane allows it to acquire a primary envelope and subsequently remove its envelope when budding through the outer nuclear membrane. Hence, it is commonly believed that two processes, envelopment and de-envelopment, are essential for nuclear egress (Mettenleiter, 2002; Goldberg et al., 2011). pUL96 assists pp150 to costabilize nucleocapsids during translocation from the nucleus to the cytoplasmic assembly compartment (Tandon and Mocarski, 2011).

\section{Viral Assembly}

The viral assembly complex (vAC), a juxtanuclear structure in the cytoplasm, is the site of viral tegumentation and envelopment, resulting in the formation of mature virus (Sanchez et al., 2000). The biogenesis of $\mathrm{vAC}$ is associated with the budding process from the secretory system, and viral pUL48 and pUL103 have been proposed to impact vAC development (Das et al., 2014). The assembly site is largely altered from a compact structure to diffuse vacuoles in the absence of functional pUL97, indicating that UL97 plays a role in vAC organization (Azzeh et al., 2006). pUL94 is in complex with pUL97 in vAC, and the interaction may contribute to viral assembly (Liu et al., 2009).

pUL94 allows correct localization and accumulation of pp28 in vAC (Phillips et al., 2012). A threshold accumulation of pp28 is required for multimerization and viral envelopmentation (Seo and Britt, 2007, 2008). Deletion of UL99 leads to the production of non-enveloped viral particles (Silva et al., 2003). UL26deleted virions also show hypophosphorylation of UL99-encoded pp28. Abnormal phosphorylation destabilizes pp28 (Munger et al., 2006), and stability of the intact viral particle is affected (Lorz et al., 2006).

pp150-nucleocapsid complex transported to vAC is dependent on the microtubule motor system, in which BicD1 protein links pp150 (acting as a cargo) and dynein (that is a motor protein), and pp150 is actively transported in a monodirectional fashion (Indran et al., 2010). pUL71 contributes to the final step of the secondary envelopment of nucleocapsid. The oligomerization catalyzed by a basic leucine zipper-like domain on pUL71 is necessary for final envelopment (Meissner et al., 2012). The viral particle can be wrapped by pUL71, which directs the complex to transport between the 
trans-Golgi network, viral assembly compartment, budding into multivesicular bodies and plasma membrane. pUL71 is localized toward the cytosolic phase of the cell membrane and covers recycling endocytic vesicles (Schauflinger et al., 2011; Dietz et al., 2018).

UL35 protein is also localized in the perinuclear region (Liu and Biegalke, 2002). More evidence based on expression of the UL35 mutant virus in transfected cells has revealed decreased production of enveloped particles and disappearance of dense bodies (DBs), indicating a role of pUL35 in envelopment (Schierling et al., 2005). Furthermore, the transport of envelope glycoprotein B is dependent on the binding of pUL35 and its interacting partner, sorting nexin 5 (SNX5) (Maschkowitz et al., 2018).

Three virus-related particles are formed and secreted from HCMV-infected cells. The first is the virion that contains the whole viral structure. Non-infectious enveloped particles that lack a viral genome are only produced in small amounts. DBs are commonly detected as incomplete viral particles that package envelope glycoproteins and some tegument proteins (Irmiere and Gibson, 1983). pp65 (pUL83) is abundant in DBs (Varnum et al., 2004). It was reported that DBs were able to induce apoptosis of Mo7e cells (Sindre et al., 2000). In vivo study revealed that $\mathrm{DBs}$ could elicit production of antibodies against glycoproteins such as $\mathrm{gH}$ and $\mathrm{gB}$ as well as tegument proteins pp65 and pp150 (Pepperl et al., 2000). Moreover, DB-delivered pp65 could be presented by MHC$\mathrm{I}$, and this antigen presentation promoted cellular immune responses (Pepperl et al., 2000). DBs have also been shown to facilitate the maturation of dendritic cells and their capacity for antigen uptake and presentation (Sauer et al., 2013). MiRNAs were detected within DBs and could be delivered into transfected cells (Mohammad et al., 2017). Recombinant DBs are vaccine candidates with efficient $\mathrm{T}$ cell and antibody responses (Becke et al., 2010).

\section{Anti-apoptosis}

Fibroblasts infected with HCMV lacking the UL38 coding sequence undergo extensively morphological changes and eventual apoptosis, prompting a role for pUL38 in preventing premature cell death (Terhune et al., 2007). pUL38 binds to ubiquitin-specific protease 24 (USP24), a protein that mediates autophagic ferritin degradation in lysosomes. This association inhibits cell death as a result of the protection of lysosome integrity because the disturbance of iron homeostasis leads to lysosome instability (Sun et al., 2018). It has also been reported that pUL38 can relieve endoplasmic reticulum (ER)-mediated cell death independent of mTORC1 (Xuan et al., 2009; Qian et al., 2011). UL36 encodes viral inhibitor of caspase- 8 activation (vICA), which modulates cell death in diverse pathways. pUL36 interacts with procaspase8 and inhibits the formation of activated caspase- 8 dimer in response to Fas-mediated apoptosis (Skaletskaya et al., 2001). It is also involved in caspase-independent apoptosis with unclear mechanisms (McCormick et al., 2010). pUL44 and IE86 act concomitantly to block p53 transcriptional activity, thus overcoming cell cycle arrest and apoptosis to accomplish cellular DNA synthesis and protein production (Kwon et al., 2012).

\section{Envelope (Table 3)}

Human cytomegalovirus is able to infect diverse cell types such as epithelial cells, fibroblasts, lymphocytes, monocytes, and macrophages, and this characterization of broad tropism is attributed to the envelope proteins that are believed to have roles in recognition, attachment, and fusion. Moreover, envelope mediators are the key to understanding cell-to-cell spread and HCMV dissemination. Entry into different cell types might be associated with concomitant effects from different combinations of envelope proteins. Three complexes termed glycoprotein complex I, II, and III (gCI, gCII, and gCIII) are present on the HCMV envelope.

\section{$\mathrm{gCl}$}

gCI comprises two subunits, gp58 and gp116, which are the products of furin protease-cleaved glycoprotein B (gB), a precursor of $160 \mathrm{kDa}$ (Vey et al., 1995). gB has been shown to play roles in viral entry into permissive cells (Isaacson and Compton, 2009) and as a target of neutralizing antibodies (Tabata et al., 2019). It contains a disintegrinlike domain that recognizes integrins, and the integrin signals are likely to promote fusion since the delivery of pp65 is increased in the presence of $\mathrm{gB}$ disintegrin-like peptide, but attachment remains unaffected (Feire et al., 2004). Binding of $\mathrm{gB}$ also triggers alteration of host signaling pathways. Upon binding, induced expression of myeloid cell leukemia $(\mathrm{Mcl})-1$ protein enhances antiapoptotic effect in non-permissive progenitor myeloid cells (Reeves et al., 2012). Small interfering RNA targeting Mcl1 exhibit increased cell death of HCMVinfected monocytes in comparison to mock infection and use of control siRNA (Chan et al., 2010). Moreover, blockade of epithelial growth factor receptor (EGFR) with specific neutralizing antibodies and pharmacological inhibitors results in the downregulation of Mcl-1 gene expression and shows similar level of cell viability to mock infection. Therefore, EGFR in monocytes appears to be an important receptor that interacts with HCMV. EGFR is further proved to be required for mediating viral entry into $\mathrm{CD}_{3}{ }^{+}$progenitor cells (Kim et al., 2017). In fibroblasts, however, HCMV infection fails to stimulate EGFR phosphorylation and activation (Isaacson et al., 2007). Viral entry is not affected in fibroblasts, epithelial and endothelial cells pretreated with EGFR antibodies (Isaacson et al., 2007). The roles of EGFR are still controversial. Further, host cells, at least monocytes, upregulate inflammatory gene expression such as interleukin-1 $\beta$ (IL-1 $\beta$ ) upon gB engagement (Yurochko and Huang, 1999).

There are various polymorphic sites along the gB-encoded UL55 gene containing 906 amino acids, with the most variable regions present in the $\mathrm{N}$-terminus, C-terminus, and furin cleavage sites (Stangherlin et al., 2017). It has been demonstrated that the genotype of $\mathrm{gB}$ differs with respect to the geographic distribution (Zipeto et al., 1998). For example, compared with patients from California, an increase in the gB4 genotype has been observed in immunocompromised patients from Italy 
TABLE 3 | HCMV envelope proteins.

\begin{tabular}{|c|c|c|c|c|}
\hline Protein & Mapped gene & Composition & Function(s) & References \\
\hline gB & UL55 & $\mathrm{gCl}$ & $\begin{array}{l}\text { Recognition } \\
\text { Attachment } \\
\text { Fusion } \\
\text { Viral entry } \\
\text { Induction of humoral immune response }\end{array}$ & Vey et al., 1995; Smuda et al., 1997 \\
\hline$g \mathrm{M}$ & UL100 & gCll & & Li et al., 1995; Varnum et al., 2004 \\
\hline$g N$ & UL73 & $\mathrm{gCll}$ & & $\begin{array}{l}\text { Dal Monte et al., 2001; Varnum et al., } \\
2004\end{array}$ \\
\hline $\mathrm{gH}$ & UL75 & gClll & & Huber and Compton, 1999 \\
\hline$g \mathrm{~L}$ & UL115 & gClll & & Huber and Compton, 1999 \\
\hline $\mathrm{gO}$ & UL74 & $\mathrm{gClll}$ & & Huber and Compton, 1999 \\
\hline $\begin{array}{l}\text { gpUL128, gpUL130. } \\
\text { gpUL131 }\end{array}$ & $\begin{array}{l}\text { UL128, UL130, } \\
\text { UL131 }\end{array}$ & $\begin{array}{l}\text { In complex with } \mathrm{gH} / \mathrm{gL} \text { on } \\
\text { envelop }\end{array}$ & & Ryckman et al., 2008; Tao et al., 2014 \\
\hline gpUL116 & UL116 & $\begin{array}{l}\text { Form complex with } \mathrm{gH} \text { on } \\
\text { envelop }\end{array}$ & & Caló et al., 2016 \\
\hline gpRL13 & $R L 13$ & & Binds to $\lg G \mathrm{Fc} \gamma$ & $\begin{array}{l}\text { Stanton et al., 2010; Li et al., 2011; } \\
\text { Cortese et al., } 2012\end{array}$ \\
\hline gpTRL10 & $R L 10$ & & Unclear & $\begin{array}{l}\text { Weekes et al., 2014; Foglierini et al., } \\
2019\end{array}$ \\
\hline gp1 & UL1 & & $\begin{array}{l}\text { Has impacts on viral growth in epithelial } \\
\text { cells but not fibroblasts }\end{array}$ & Shikhagaie et al., 2012 \\
\hline gp48 & UL4 & & Has no impact on viral growth in fibroblasts & Hobom et al., 2000 \\
\hline gp42 & UL132 & & $\begin{array}{l}\text { Has impacts on viral growth in fibroblasts } \\
\text { Endocytosis of gp } 42 \text { into virion is required } \\
\text { for efficient replication }\end{array}$ & $\begin{array}{l}\text { Spaderna et al., 2005; Kropff et al., } \\
2010\end{array}$ \\
\hline
\end{tabular}

(Zipeto et al., 1998). Infection by HCMV with different gB genotypes may not share a comparable natural disease course (Roubalová et al., 2010). gB1 and gB2 types are often seen in patients with transplantation and infection with human immunodeficiency virus (HIV), respectively (Fries et al., 1994; Shepp et al., 1996). The $275 \mathrm{Y}$ variants of $\mathrm{gB}$ expressed on the AD169 strain promote fusogenicity with activation of caspase 2 and the DNA damage response since the 275D variants show less syncytium formation and an inability to trigger caspase 2 (Tang et al., 2019). Whether gB genotypes are associated with cell tropism are largely elusive.

\section{gCII}

gCII is designated as a complex that is formed covalently and non-covalently by gM together with gN, which are the products of UL100 and UL73 ORFs, respectively (Mach et al., 2000; Varnum et al., 2004). Formation of the $\mathrm{gM} / \mathrm{gN}$ complex in the $\mathrm{ER}$ is required for transport and intracellular trafficking of the heterodimer to the mature virion assembly center (Mach et al., 2005). Binding to cell surface heparan sulfate proteoglycans (HSPGs) is the initial step in which virus tethers and attaches to the host (Compton et al., 1993). gCII (Kari and Gehrz, 1992) and soluble gB (Boyle and Compton, 1998) are interaction partners of heparin, and the interactions thus facilitate viral attachment and entry. Similar to gB, gM and gN elicit humoral responses in which neutralizing antibodies are produced (Shen et al., 2007). Anti-gM/gN antibodies may be able to recognize HCMV unlimited by strain specification since anti-gM/gN IgG antibodies generated from AD169 can bind to the Toledo strain (Shimamura et al., 2006).

\section{gCIII}

gCIII contains the $\mathrm{gH} / \mathrm{gL} / \mathrm{gO}$ complex, a high-molecular-weight complex (Kinzler et al., 2002). This is further complicated by the fact that co-expression of the UL75 (gH), UL115 (gL), and UL74 (gO) genes does not readily result in the formation of the tripartite complex (Huber and Compton, 1999). gH binding triggers activation of transcription factors such as NK$\kappa \mathrm{B}$, a process that can be blocked by anti-gH neutralizing antibodies (Yurochko et al., 1997). The UL74 sequence shows variations, leading to a growing recognition of the functional importance of gO (Paterson et al., 2002). Further studies have described an increased sensitivity of UL74-deleted HCMVinfected fibroblasts in the context of anti-HCMV serum, anti-gB antibodies, and anti-gH antibodies (Jiang et al., 2011). In addition to the $\mathrm{gH} / \mathrm{gL} / \mathrm{gO}$ complex, $\mathrm{gH} / \mathrm{gL}$ interact with UL128-131 gene products. The different constitutions of the two complexes are associated with cell-specific tropism. The $\mathrm{gH} / \mathrm{gL} / \mathrm{gO}$ complex is required for entry and dissemination between fibroblasts, while viral entry into epithelial and endothelial cells requires the $\mathrm{gH} / \mathrm{gL} / \mathrm{UL} 128-131$ complex to bind to cognate receptors (Huber and Compton, 1998; Wang and Shenk, 2005; Adler et al., 2006). In addition, UL128-131A gene products are required for efficient internalization into monocytes via integrin-mediated signaling (Nogalski et al., 2013), and they are crucial for infection of monocytes (Straschewski et al., 2011) and dendritic cells (Gerna et al., 2005).

\section{Other Proteins}

Stanton et al. (2010) assumed that the highly glycosylated RL13 protein may be a surface envelope protein. Its role on envelope 
was further studied by another group (Cortese et al., 2012). Fc $\gamma$ signals could be detected though flow cytometry in RL13expressed HEK293T cells that were exposed to DyLight 649conjugated human $\mathrm{Fc} \gamma$, suggesting that RL13 interacted with Fc $\gamma$. This result was further confirmed by confocal microscopy analysis that showed colocalization of Fc $\gamma$ and RL13 (Cortese et al., 2012). Therefore, RL13 has Fc binding abilities. Four viral encoded G-protein coupled receptors (GPCRs) are also viral membrane proteins, which have been intensively reviewed (Krishna et al., 2018; Frank et al., 2019). Their functions are briefly summarized in Table 4.

\section{DIFFERENT SIGNIFICANCES OF VIRION-CARRIED MOLECULES IN PRIMARY INFECTION AND REACTIVATION}

\section{Roles of pp71 in Primary Infection and Reactivation (Figure 1)}

Lifelong HCMV infection is attributed to its latency in healthy individuals. Single-cell transcriptomic analysis found that the transcription program in the latently infected cells mirrors that at the late phase of lytic replication, but the latency-associated expression level is low (Shnayder et al., 2018). Viral abilities to re-express lytic genes from the quiescent form in response to certain stimuli are associated with complications such as severe pneumonia and gastrointestinal disease following transplantation (Zhao et al., 2017). CD $34^{+}$HPCs and $\mathrm{CD}^{+} 4^{+}$monocytes do not provide a platform for viral replication, and undifferentiated cells are considered to be the latent reservoirs of HCMV (Mendelson et al., 1996; Khaiboullina et al., 2004). Nuclear pp71 can be detected by immunofluorescence in normal human dermal fibroblasts (NHDFs), the permissive cells for HCMV lytic replication. By contrast, pp71 is retained in the cytoplasm instead of the nucleus of HPCs (Saffert and Kalejta, 2007). Interestingly, the process of viral entry into $\mathrm{CD}_{3}{ }^{+} \mathrm{HPCs}$ by macropinocytosis does not allow pp71 to escape from endosomes, and endosome retention is at least one possible mechanism that ensures the cytoplasmic localization of pp71 in HPCs (Lee and Kalejta, 2019). Cytoplasmic localization of pp71 has also been observed in NTERA-2 (NT2) cells that are incompletely differentiated cell lines (Penkert and Kalejta, 2010). The pp71 subcellular localization is crucial for its transactivities and therefore associated with the replicative or latent phase. The underlying mechanism is largely determined by the interaction of pp71 with components of the ND10 (Hofmann et al., 2002).

Promyelocytic leukemia protein (PML)-associated nuclear bodies (also known as ND10), subnuclear spherical and punctate structures that are, on average, 0.3 to $0.5 \mu \mathrm{m}$ in size (Ahn et al., 1999), are thought to be the location for input viral DNA accumulation (Ishov and Maul, 1996). Death domain-associated protein (Daxx), one of the most important components in ND10, acts as an intrinsic defense mechanism against HCMV by restriction of viral gene expression as demonstrated by the inhibition of viral replication in cells overexpressing Daxx (Cantrell and Bresnahan, 2006). Daxx-induced HCMV transcriptional repression promotes the establishment of latent states (Saffert and Kalejta, 2007). Daxx and other ND10 proteins that bind to transcriptional factors are able to recruit histone deacetylases (HDACs) (Hollenbach et al., 2002; Maul, 2008).

\begin{tabular}{|c|c|c|c|}
\hline Protein & Mapped gene & Function(s) & References \\
\hline pUL33 & UL33 & $\begin{array}{l}\text { - Co-localizes, interacts and further blocks US28-induced NK-кB } \\
\text { activation } \\
\text { - Enhances transcription mediated by cAMP responsive element } \\
\text { - Forms a complex with pUL78, host CCR5 and CXCR4, and impairs } \\
\text { CXCR4 effects } \\
\text { > Has oncomodulatory properties }\end{array}$ & $\begin{array}{l}\text { Fraile-Ramos et al., 2002; Casarosa et al., 2003; } \\
\text { Tschische et al., 2011; Tadagaki et al., 2012; van } \\
\text { Senten et al., } 2019\end{array}$ \\
\hline pUL78 & UL78 & $\begin{array}{l}\text { - Co-localizes, interacts and further blocks US28-induced NK-кB } \\
\text { activation } \\
\text { - Form a complex with pUL33, host CCR5 and CXCR4, and impairs } \\
\text { CXCR4 effects } \\
\text { - Has impacts on viral growth in epithelial and endothelial cells but not } \\
\text { fibroblasts }\end{array}$ & $\begin{array}{l}\text { Michel et al., 2005; Tschische et al., 2011; } \\
\text { O'Connor and Shenk, } 2012\end{array}$ \\
\hline gpUS27 & US27 & $\begin{array}{l}\text { = Promotes CXCL12/CXCR4 signaling } \\
\text { = Increases surface CXCR4 level } \\
\text { - Facilitates CXCR4 internalization after CXCL12 binds } \\
\text { - Stimulates expression of stress response genes } \\
\text { = Increases DNA replication } \\
\text { = Induces pro-survival factors such as Bcl-x }\end{array}$ & $\begin{array}{l}\text { Fraile-Ramos et al., 2002; Lares et al., 2013; Boeck } \\
\text { and Spencer, 2017; Boeck et al., 2018; Tu et al., } \\
2018\end{array}$ \\
\hline pUS28 & US28 & $\begin{array}{l}\text { - Acts as chemokine receptors, has multiple ligands and activates multiple } \\
\text { signaling pathways } \\
\text { - Chemokine internalization } \\
\text { - Promotes survival } \\
\text { - Activates MIEP in differentiated cells } \\
\text { - Promotes latency in undifferentiated cells }\end{array}$ & $\begin{array}{l}\text { Fraile-Ramos et al., 2002; Krishna et al., 2017a, } \\
\text { 2018; Zhu et al., 2018; Frank et al., } 2019\end{array}$ \\
\hline
\end{tabular}




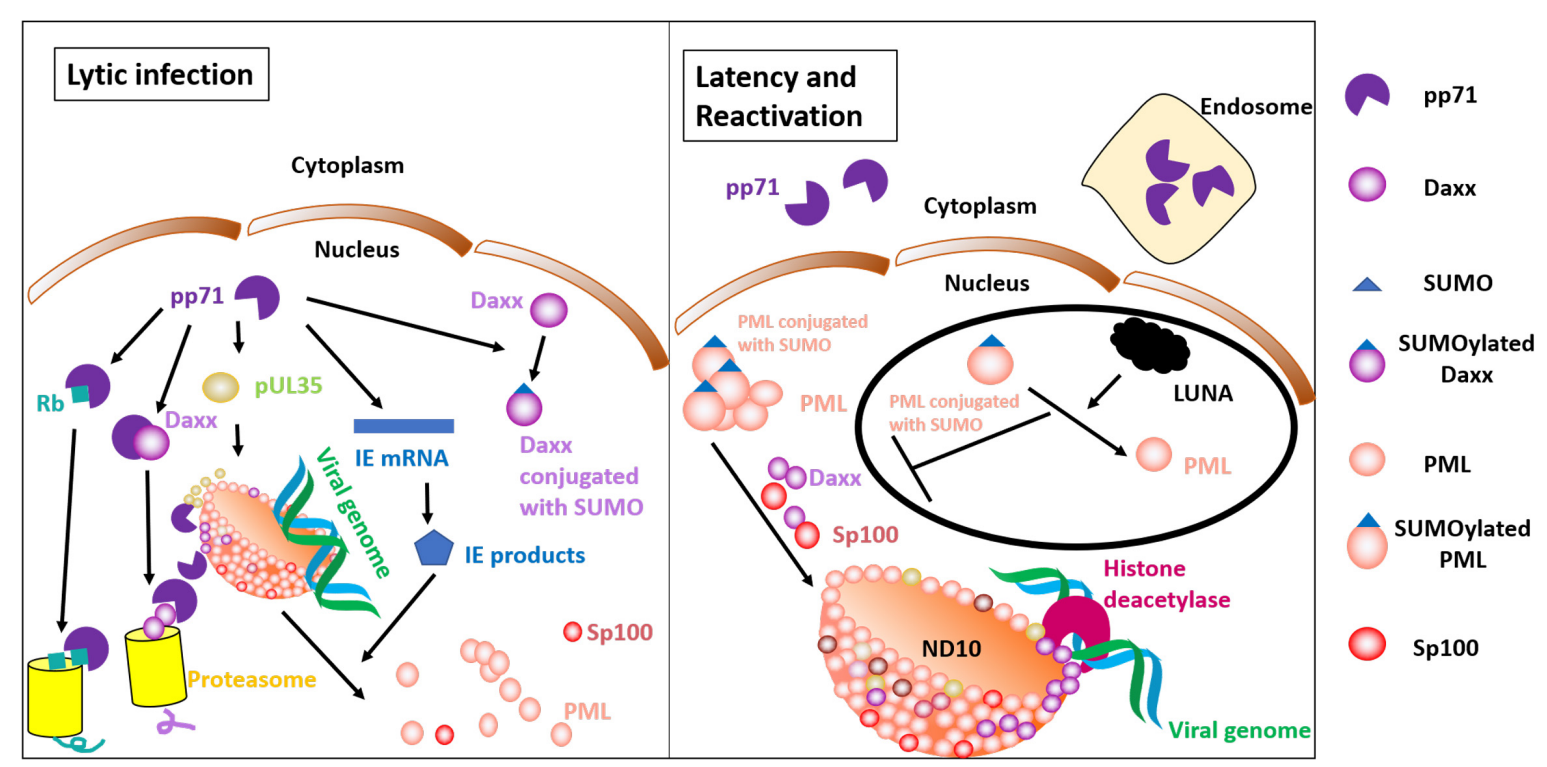

FIGURE 1 | Roles of pp71 in the lytic and latent phase. The left panel shows lytic gene expression. Nuclear pp71 is capable of promoting pUL35 to recruit PML, an ND10 component that has impacts on correct localization of Daxx and Sp100. pp71 interacts with Daxx and induces Daxx for degradation in a proteasome-dependent manner. pp71 transactivates IE gene expression, and IE products disrupt ND10. pp71 also has abilities to induce Rb degradation, a process that contributes to relieve Rb-mediated cell cycle block. The right panel shows the latent state and reactivation. pp71 is retained in the cytoplasm or endosome rather than the nucleus. ND10 components represent an intrinsic defense mechanism. Daxx, PML, and bound transcription factors recruit histone deacetylases, resulting in viral gene silencing. LUNA-mediated reactivation is shown in a black circle. LUNA contains isopeptidase activity that deSUMOylates PML and disrupts PML-induced recruitment of Daxx and Sp100. Therefore, LUNA promotes reactivation.

The major immediate early promotor (MIEP)-bound histones are unacetylated in undifferentiated cells (Reeves et al., 2005), and thus MIEP that drives lytic replication is transcriptionally inert. Downregulation of Daxx results in failed formation of heterochromatin and increased IE gene expression (Woodhall et al., 2006). Moreover, Daxx together with ATRX forms a complex that is considered to be a H3.3 histone chaperone that affects H3.3 deposition on heterochromatin (Lewis et al., 2010). In addition to Daxx, other components of ND10, including PML and Sp100, also contribute to viral genome repression (Glass and Everett, 2013). Compared with the knockdown of Daxx alone using siRNA, triple deletion of Daxx, PML, and Sp100 can more efficiently inhibit gene expression and viral production (Glass and Everett, 2013). In the absence of PML, Daxx and Sp100 show a dispersed distribution and disrupted colocalization (Tavalai et al., 2006).

By two-yeast hybrid system screening (Hofmann et al., 2002) and immunoprecipitation (Hofmann et al., 2002; Ishov et al., 2002), pp71 has been found to be an interactor with Daxx. Hofmann et al. also confirmed colocalization of Daxx and pp71 (Hofmann et al., 2002). A mutant version of pp71 that lacks binding ability to Daxx is unable to transactivate IE expression (Hofmann et al., 2002). Therefore, the association of pp71 and Daxx is pivotal for the functions of pp71. pp71 proteins are accumulated in the nucleus prior to IE2 transcription (Ishov et al., 2002). The following study reported that pp71 was able to induce Daxx degradation through proteasome, independent of ubiquitin (Hwang and Kalejta, 2007). Daxx degradation is critical for pp71 functions in transactivation since Daxx plays roles in the recruitment of HDACs, heterochromatin formation, and transcriptional repression (Hollenbach et al., 2002; Woodhall et al., 2006). Acetylation of MIEP-associated histones was detected when latently infected $\mathrm{CD}_{3} 4^{+}$progenitor cell terminally differentiated into dendritic cell, a permissive cell type that supports the HCMV productive phase (Reeves et al., 2005). Furthermore, pp71 also promotes Daxx SUMOylation, but this posttranslational modification is unable to affect pp71 transactivity (Hwang and Kalejta, 2009). SUMOylation of PML is required to recruit Daxx (Ishov et al., 1999), but the effect of SUMOylation still needs to be investigated. The interplay between ND10 and pp71 is further complicated by evidence showing that pp71 facilitates the UL35 gene products pUL35 to form UL35 nuclear bodies, which are capable of recruiting PML, Daxx, and Sp100 (Salsman et al., 2011). The transfected cells infected with mutant virus that harbors deletions in the UL35 gene show decreased IE gene expression (Schierling et al., 2005). UL35a protein, a short-sized UL35 gene product, however, shows reduced formation of UL35 nuclear bodies and contributes to pp71 cytoplasmic localization (Salsman et al., 2011). Indeed, previous research has reported that pUL35a inhibits pp71-mediated MIEP activation (Liu and Biegalke, 2002). However, unlike pUL35 that was found in virions, pUL35a is not packaged into the mature virion, and its transcripts are detected $4 \mathrm{~h}$ after infection (Liu and Biegalke, 2002). It is likely that pUL35 plays roles earlier than pUL35a as pUL35 is a preexisting protein. After pp71 degrades Daxx and activates IE 
gene expression, IE gene products disperse and disrupt ND10 (Korioth et al., 1996; Ishov et al., 1997). A recent study has reported that LUNA-mediated deSUMOylation is required for PML dispersal (Poole et al., 2018).

Less efficient reactivation has been detected in dendritic cells that are differentiated from $\mathrm{CD}_{3} 4^{+}$progenitor cells infected with LUNA-defective HCMV, compared to wild-type HCMV infection (Poole et al., 2018). In contrast, viral production in fibroblasts shows no differences between wild-type and LUNA knockdown group (Poole et al., 2018). Further, in comparison to wild type, PML knockdown results in increased numbers of cells that prime IE gene expression of fibroblasts (Tavalai et al., 2006), but no distinction in IE-forming units in the reactivation model (Poole et al., 2018). Heterogeneous cell fusion experiments in which NHDFs form syncytia with viral-infected NT2 cells showed that pp71 proteins that were previously localized in the NT2 cytoplasm were detected in nuclei in syncytia, indicating that terminally differentiated cells provide factors that promote pp71 nuclear accumulation (Penkert and Kalejta, 2010). As discussed above, pp71 cytoplasmic or nuclear localization contributes to the establishment of the latent or replicative phase, respectively. However, reactivation can occur at various times after the initial infection. This process is unlikely to utilize the pp71 retained in the cytoplasm. Moreover, latency-associated pp71 expression is not significantly high (Cheng et al., 2017). Whether pp71 is crucial for IE gene expression during reactivation is unclear, and this knowledge may hold the key to understanding HCMV-associated disease and even mortality posttransplantation. Together, there might be differences in the initiation of IE transcription in primary infection and reactivation.

\section{Roles of pUS28 in Primary Infection and Reactivation}

pUS28, a virally expressed GPCR, shares homology with human chemokine receptor (Gao and Murphy, 1994) and is able to interact with diverse CC and $\mathrm{CX}(3) \mathrm{C}$ chemokines (Gao and Murphy, 1994; Kledal et al., 1998). The US28 gene is transcribed in both the lytic and latent phases (Beisser et al., 2001). Recent transcriptome analysis has confirmed latency-associated transcription in both natural CD34 ${ }^{+}$HPCs and experimentally latent models (Cheng et al., 2017). Deletion of US28 results in the failed establishment of latency. Also, in undifferentiated monocytes, MIEP is associated with phosphorylated $\mathrm{H} 3$ (a histone marker of transcriptional activation) and heterochromatin protein 1 in the absence and presence of US28 respectively (Krishna et al., 2017a). These findings suggest that pUS28 plays a role in the promotion of the latent phase. Moreover, the authors further found that functional pUS28 was able to increase MIEP activities of differentiated cells (Krishna et al., 2017a). Together, these data show that pUS28 has different effects on the lytic and latent phases, and activities of pUS28 are heavily dependent on the differentiation states. The point mutation R129A in US28 results in an inability to activate or repress signaling pathways, and Y16F leads to pUS28 that is incapable of binding to chemokines. Expression of US28 with Y16F by lentivirus complements pUS28-mediated latency, whereas R129A does not, demonstrating that Y16F does not affect pUS28-induced latency, and signaling pathway alteration is linked to the effects of pUS28 on latency establishment (Krishna et al., 2017a). Further, pUS28 is likely to dephosphorylate MAPK and $\mathrm{NK}-\kappa \mathrm{B}$ factors in undifferentiated cells, at least partially contributing to the establishment of latency. It has opposite impacts on differentiated cells, namely, hyperphosphorylation of signaling molecules to facilitate lytic infection (Krishna et al., 2017a). A recent report discovered that HCMV forces HPCs into a monocyte subset characterized by a longer lifespan and immunosuppressive phenotype via STAT3-iNOSNO cascade to achieve latency (Zhu et al., 2018). Deletion of US28 leads to STAT3 inactivation and subsequent failure of latent establishment, indicating that pUS28-mediated STAT3 phosphorylation is essential for latency (Zhu et al., 2018).

\section{Roles of Virion-Carried Molecules in Nuclear Targeting During Primary Infection}

Nuclear targeting is a process of transportation of incoming nucleocapsid to host nucleus, and this process is dispensable for reactivation. The bipartite NLS of pUL48 mediates nuclear targeting, a process that targets the nucleocapsid toward the host nucleus and releases the viral genome into the cell nucleus (Brock et al., 2013). pUL48 may cooperate with pUL47 to promote disassembly of the nucleocapsid and enhance the release of viral DNA from the capsid (Bechtel and Shenk, 2002). pUL47 is a pUL48-binding protein, and the interaction facilitates cleavage of isopeptide bonds via the deubiquitylating activity of pUL48 (Tullman et al., 2014). A mutant virus that lacks deubiquitinating activity shows decreased replication and dissemination as a result of reduced autodeubiquitination (Kim Y. E. et al., 2016).

Tegument proteins preserve the integrity of the capsid that houses an incompatible large genome. The $150-\mathrm{kDa}$ phosphoprotein encoded by the UL32 gene, a second abundant component of the tegumental layer, was found to interact with the triplex on the capsid and to extend toward the SCP (Yu et al., 2017). The subcellular localization of pp150-nucleus or cytoplasm-is still controversial, and it may accompany the capsid and transit from nucleus to cytoplasm (Sanchez et al., 2000; Sampaio et al., 2005). Nevertheless, pp150 is thought to be involved in nuclear targeting during primary infection, organization of the assembly compartment, tegumentation, and virion egress during late infection due to its extensive structural associations with the nucleocapsid (AuCoin et al., 2006; Tandon and Mocarski, 2008; Indran et al., 2010).

\section{Roles of Virion-Carried Molecules in Host Cell Cycle Regulation}

Viral replication is a complex cascade that requires the host cells to provide replicative factors and nutrients, and those substances supplied during cell division are not sufficient for viral growth, especially for HCMV with a long replication cycle. Hence, HCMV develops strategies to arrest host in the G1/S phase to accomplish the whole lytic replication cycle. In primary infection, virally delivered factors can be readily used to regulate the host cell cycle. 
Viral pUL21a destabilizes cyclin A2 via a conserved cyclin A2 binding motif, arginine-x-leucine (RxL), via proteasomedependent degradation to arrest host cell cycle progression (Caffarelli et al., 2013). Overexpression of cyclin A2 renders host cells entry into mitotic phase (Eifler et al., 2014). pUL21a further modulates the host cell cycle by degrading anaphasepromoting complex/cyclosome (APC/C) subunits that serve as an E3 ubiquitin ligase that digest certain proteins in the G1 and M phase to regulate the cell cycle (Fehr et al., 2012). pp150 mutant virus that lacks binding ability to cyclin $\mathrm{A} 2$ is unable to arrest hosts in the S/G2 block, but cell gene expression is restricted at the G2/M phase (Weisbach et al., 2017). Double mutation of pp150 and pUL21a, both of which are unable to interact with cyclin A2, results in unrestricted G2 and mitotic entry (Weisbach et al., 2017). Those data indicate that pp 150 and pUL21a concomitantly reprogram the cell cycle (Weisbach et al., 2017). In response to stress signaling such as viral infection, tuberous sclerosis protein complex 2 (TSC2) is activated, which in turn blocks mTORC1 activities, halting cell growth (Moorman et al., 2008). mTORC1 can also be activated by pUL38 in a TSC2-independent pathway, suggesting that pUL38 is able to modulate cell growth (Moorman et al., 2008; Bai et al., 2015). pUL69 has also been reported to induce G1 blockade (Lu and Shenk, 1999; Hayashi et al., 2000).

If the host is default to pass through the S/G2 phase and undergo subsequent division, HCMV replication is decreased to wait for a time that allows sufficient viral growth. Cellcycle-associated IE gene repression is independent of intrinsic defense mechanisms such as PML (Zydek et al., 2011). The viral reproductive cycle can be inhibited with high levels of cyclin $A$ in the S/G2 phases, and the interaction between pp150 and cyclin A is essential for inhibition (Weisbach et al., 2017). pp150cyclin A2-CDK activities in the S/G2 phases interfere with viral IE gene expression by blocking IE gene expression and affecting IE mRNA splicing (Oduro et al., 2012; Bogdanow et al., 2013). Therefore, once the sensor protein pp150 binds to cyclin A, HCMV transiently shuts down IE gene expression to ensure that viral lytic replication does not take place in the time course of host cell division (Bogdanow et al., 2013).

In the quiescent state, retinoblastoma $(\mathrm{Rb})$ forms a complex with E2F, inhibiting the expression of E2F-responsive genes and subsequent cell cycle progression. Rb (Hume et al., 2008) and its family members (Iwahori et al., 2017) are phosphorylated by viral pUL97. Hyperphosphorylation and inactivation of Rb by pUL97 activates E2F-mediated transcription and cell cycle progression (Iwahori et al., 2015). Moreover, Rb interacts with ND10-associated proteins (Alcalay et al., 1998), enhancing the transcriptional repression of the viral genome (Fang et al., 2002). Hyperphosphorylation of Rb by pUL97 relieves this negative effect in a PML-dependent manner (Fang et al., 2002). Additional mechanisms are also involved in the regulation of $\mathrm{Rb}$ family members. pp71 degrades $\mathrm{Rb}$ proteins by the proteasome (Figure 1; Kalejta and Shenk, 2003).

Reactivation is highly dependent on cell differentiation states. Upon treatment of interleukin-4 (IL-4) and granulocyte macrophage/colony stimulating factor (GM/CSF), experimentally latent $\mathrm{CD} 14^{+}$monocytes differentiate into immature dendritic cells (DCs) that do not display robust lytic replication (Reeves and Compton, 2011). Additional treatment of lipopolysaccharide (LPS) and interleukin-6 (IL-6) transforms immature cells into mature DCs that support HCMV reactivation, suggesting that differentiation and inflammation are two leading stimuli for viral reactivation (Reeves and Compton, 2011). Thus, reactivation occurs in final differentiated cells and relatively independent of regulation of the host cell cycle.

\section{HCMV PROTEIN RELATED ANTI-VIRAL THERAPY}

The most common antiviral drugs used to control HCMV infection are ganciclovir (GCV), valganciclovir, foscarnet, and cidofovir. Valganciclovir, the prodrug of ganciclovir, can be metabolized to GCV, an analog of nucleoside guanosine. GCV is activated by phosphorylation catalyzed by pUL97 and cellular kinases to form ganciclovir triphosphate, terminating viral DNA synthesis by incorporation into the newly produced DNA strand and inhibition of pUL54 DNA polymerase activities (Matthews and Boehme, 1988). Therefore, mutations in UL54 or UL97 or both give rise to drug resistance, with more cases related to UL97 mutations, for example, deletions of codon 594 in the UL97 genes (Keyvani et al., 2016) and point mutations such as M460V/I, H520Q, N510S, C592G and C603W (Cocohoba and McNicholl, 2002; Bachmann et al., 2013). Cidofovir is an analog of deoxycytidine monophosphate, which is further phosphorylated to a deoxycytidine triphosphate analog. Post-hematopoietic stem cell transplantation (HSCT) patients generally do not benefit from brincidofovir, a lipid conjugated cidofovir, applied for HCMV prophylaxis. All-cause mortality was 15.5 and $10.1 \%$ in the brincidofovir and placebo group, respectively (Marty et al., 2019). A similar approach is employed by cidofovir triphosphate to block pUL54 activities. Foscarnet is also an alternative choice because it inhibits pyrophosphate binding site on pUL54, and thus, pyrophosphate is not able to be cleaved from nucleotides. These available antiviral agents are limited by resistance, poor bioavailability as well as acute and long-term adverse effects such as severe myelosuppression. Most anti-HCMV drugs in widespread use were developed to target pUL54 polymerase, while maribavir interacts with pUL97 and disrupts the kinase activities of pUL97 (Razonable, 2018). Maribavir had comparable effects to valganciclovir in the control of HCMV viremia in the posttransplantation settings in a phase two trial (Maertens et al., 2019). However, it is difficult to determine or distinguish whether the HCMV viremia results from primary infection or reactivation. Therefore, whether the drug has different efficacies in primary infection and reactivation are unknown. Letermovir targets pUL56, the large subunit of the terminase complex that plays roles in DNA cleavage/packaging (Ligat et al., 2018). In a phase 2 clinical trial that administered letermovir as prophylaxis therapy to HCMV-seropositive patients after HSCT, letermovir (at a dose of 120 and $240 \mathrm{mg}$ per day) was shown to significantly reduce HCMV reactivation compared with placebo (Chemaly et al., 2014). ASP0113, a DNA-based vaccine, contains plasmids encoding gB and pp65 (Smith et al., 2013). However, the prevention efficacy is not significant in $\mathrm{D}^{+} / \mathrm{R}-$ 
kidney transplantation (Vincenti et al., 2018). gB vaccine with MF59 adjuvant has been reported to reduce congenital primary infection (Pass et al., 2009). Moreover, gB vaccine was also effective for decreasing reactivation rates in $\mathrm{D}^{+} / \mathrm{R}-$ post HSCT (Griffiths et al., 2011).

New methods have been developed following advances in molecular biology. In vitro studies have shown a promising therapeutic method using siRNAs targeting gene transcripts of UL54, UL97, and UL122/123. Despite the high efficacy in vitro, no in vivo analysis has been published (Hamilton et al., 2014). However, other studies have demonstrated that siRNA targeting UL54 is less effective and has limited utility (Shin et al., 2006). Viral GPCR pUS28 is expressed at the host membrane to interact with chemokines and triggers internalization once engaged. F49A-fusion toxin proteins (F49A-FTP) can bind to pUS28 to subsequently mediate endocytosis. The coupled toxin has cytotoxic effects on target cells. This novel strategy was shown to efficiently kill targets with lytic infection (Spiess et al., 2015) and to reduce reactivation of cells latently infected with HCMV (Krishna et al., 2017b).

\section{SUMMARY}

Human cytomegalovirus infects large populations and becomes dormant in primitive progenitor cells. Reactivation in transplant recipients can lead to severe CMV disease and cause death. Usage of virion-carried mediators (especially surface glycoproteins and tegument proteins) is associated with biological processes during primary infection, latency, and reactivation. Viral envelope proteins determine cell tropism in primary infection and dissemination. They act as targets for neutralizing antibodies and vaccines. Tegument links the envelope and nucleocapsid. Although the limited amounts of some tegument proteins are not sufficient to complete associated biological processes, they still participate in viral life cycle and merit discussion. Unlike primary infection in which virion-carried proteins can assist HCMV to reconcile the host to favor viral proliferation, they cannot be readily used by viruses in the context of reactivation.

\section{REFERENCES}

Adair, R., Douglas, E. R., Maclean, J. B., Graham, S. Y., Aitken, J. D., Jamieson, F. E., et al. (2002). The products of human cytomegalovirus genes UL23, UL24, UL43 and US22 are tegument components. J. Gen. Virol. 83(Pt 6), 1315-1324. doi: 10.1099/0022-1317-83-6-1315

Adler, B., Scrivano, L., Ruzcics, Z., Rupp, B., Sinzger, C., and Koszinowski, U. (2006). Role of human cytomegalovirus UL131A in cell type-specific virus entry and release. J. Gen. Virol. 87(Pt 9), 2451-2460. doi: 10.1099/vir.0.81921-0

Ahn, J. H., Jang, W. J., and Hayward, G. S. (1999). The human cytomegalovirus IE2 and UL112-113 proteins accumulate in viral DNA replication compartments that initiate from the periphery of promyelocytic leukemia protein-associated nuclear bodies (PODs or ND10). J. Virol. 73, 10458-10471. doi: 10.1128/jvi.73. 12.10458-10471.1999

Akter, P., Cunningham, C., McSharry, B. P., Dolan, A., Addison, C., Dargan, D. J., et al. (2003). Two novel spliced genes in human cytomegalovirus. J. Gen. Virol. 84(Pt 5), 1117-1122. doi: 10.1099/vir.0.18952-0

Alcalay, M., Tomassoni, L., Colombo, E., Stoldt, S., Grignani, F., Fagioli, M., et al. (1998). The promyelocytic leukemia gene product (PML) forms stable
Those packaged proteins such as pp71 are differentially used in primary infection and reactivation. Some biological processes, such as nuclear targeting, are unique to primary infection, and thus proteins involved in such processes predominantly play roles in primary infection rather than reactivation. The mechanism by which HCMV rapidly produces molecules that enhance re-expression of lytic genes holds the key to understanding reactivation. Moreover, although the virus becomes latent in HPCs upon initial infection, the strategies used by HCMV to dampen immune response toward virion-delivered foreign molecules such as glycoproteins on envelope and tegument proteins remain to be understood.

\section{AUTHOR CONTRIBUTIONS}

Y-QW wrote the manuscript. X-YZ outlined the manuscript and made a deep intellectual contribution to the work. Both authors listed approved the final version of the manuscript.

\section{FUNDING}

This work was supported by the National Key Research and Development Program of China (No. 2017YFA0104500), the National Natural Science Foundation of China (Nos. 81670166, 81530046, and 81870140), the Innovative Research Groups of the National Natural Science Foundation of China (No. 81621001), the Beijing Municipal Science \& Technology Commission (No. Z171100001017098), the Project of Health Collaborative Innovation of Guangzhou City (No. 201704020214), the Scientific Research Foundation for Capital Medicine Development (No. 2018-2-4084), the Peking University Clinical Scientist Program (No. BMU2019LCKXJ003), and Clinical Medicine Plus X-Young Scholars Project of Peking University (No. PKU2020LCXQ015) supported by "the Fundamental Research Funds for the Central Universities," and Peking University People's Hospital Research and Development Funds (No. RDX2019-14). complexes with the retinoblastoma protein. Mol. Cell. Biol. 18, 1084-1093. doi: $10.1128 / \mathrm{mcb} .18 .2 .1084$

Alvisi, G., Marin, O., Pari, G., Mancini, M., Avanzi, S., Loregian, A., et al. (2011). Multiple phosphorylation sites at the C-terminus regulate nuclear import of HCMV DNA polymerase processivity factor ppUL44. Virology 417, 259-267. doi: 10.1016/j.virol.2011.06.015

Anders, D. G. (1990). Nucleotide sequence of a cytomegalovirus single-stranded DNA-binding protein gene: comparison with alpha- and gammaherpesvirus counterparts reveals conserved segments. J. Gen. Virol. 71(Pt 10), 2451-2456. doi: 10.1099/0022-1317-71-10-2451

Aoyagi, M., Gaspar, M., and Shenk, T. E. (2010). Human cytomegalovirus UL69 protein facilitates translation by associating with the mRNA cap-binding complex and excluding 4EBP1. Proc. Natl. Acad. Sci. U.S.A. 107, 2640-2645. doi: 10.1073/pnas.0914856107

Arcangeletti, M. C., Rodighiero, I., Mirandola, P., De Conto, F., Covan, S., Germini, D., et al. (2011). Cell-cycle-dependent localization of human cytomegalovirus UL83 phosphoprotein in the nucleolus and modulation of viral gene expression in human embryo fibroblasts in vitro. J. Cell. Biochem. 112, 307-317. doi: $10.1002 /$ jcb. 22928 
AuCoin, D. P., Smith, G. B., Meiering, C. D., and Mocarski, E. S. (2006). Betaherpesvirus-conserved cytomegalovirus tegument protein ppUL32 (pp150) controls cytoplasmic events during virion maturation. J. Virol. 80, 8199-8210. doi: 10.1128/jvi.00457-06

Azzeh, M., Honigman, A., Taraboulos, A., Rouvinski, A., and Wolf, D. G. (2006). Structural changes in human cytomegalovirus cytoplasmic assembly sites in the absence of UL97 kinase activity. Virology 354, 69-79. doi: 10.1016/j.virol.2006. 05.037

Bachmann, R., Hamprecht, K., Lange, J., Ladurner, R., Nadalin, S., Jahn, G., et al. (2013). Successful ganciclovir treatment of primary cytomegalovirus infection containing the UL97 mutation N510S in an intestinal graft recipient. Infection 41, 875-879. doi: 10.1007/s15010-013-0458-3

Bai, Y., Xuan, B., Liu, H., Zhong, J., Yu, D., and Qian, Z. (2015). Tuberous Sclerosis Complex Protein 2-Independent Activation of mTORC1 by Human Cytomegalovirus pUL38. J. Virol. 89, 7625-7635. doi: 10.1128/jvi.01027-15

Battista, M. C., Bergamini, G., Boccuni, M. C., Campanini, F., Ripalti, A., and Landini, M. P. (1999). Expression and characterization of a novel structural protein of human cytomegalovirus, pUL25. J. Virol. 73, 3800-3809. doi: 10. 1128/jvi.73.5.3800-3809.1999

Bechtel, J. T., and Shenk, T. (2002). Human cytomegalovirus UL47 tegument protein functions after entry and before immediate-early gene expression. J. Virol. 76, 1043-1050. doi: 10.1128/jvi.76.3.1043-1050.2002

Becke, S., Aue, S., Thomas, D., Schader, S., Podlech, J., Bopp, T., et al. (2010). Optimized recombinant dense bodies of human cytomegalovirus efficiently prime virus specific lymphocytes and neutralizing antibodies without the addition of adjuvant. Vaccine 28, 6191-6198. doi: 10.1016/j.vaccine.2010.07.016

Beisser, P. S., Laurent, L., Virelizier, J. L., and Michelson, S. (2001). Human cytomegalovirus chemokine receptor gene US28 is transcribed in latently infected THP-1 monocytes. J. Virol. 75, 5949-5957. doi: 10.1128/jvi.75.13.59495957.2001

Bender, B. J., Coen, D. M., and Strang, B. L. (2014). Dynamic and nucleolindependent localization of human cytomegalovirus UL84 to the periphery of viral replication compartments and nucleoli. J. Virol. 88, 11738-11747. doi: 10.1128/jvi.01889-14

Bhella, D., Rixon, F. J., and Dargan, D. J. (2000). Cryomicroscopy of human cytomegalovirus virions reveals more densely packed genomic DNA than in herpes simplex virus type 1. J. Mol. Biol. 295, 155-161. doi: 10.1006/jmbi.1999. 3344

Biolatti, M., Dell'Oste, V., Pautasso, S., Gugliesi, F., von Einem, J., Krapp, C., et al. (2018a). Human Cytomegalovirus Tegument Protein pp65 (pUL83) Dampens Type I Interferon Production by Inactivating the DNA Sensor cGAS without Affecting STING. J. Virol. 92:e001774-17. doi: 10.1128/jvi.01774-17

Biolatti, M., Dell'Oste, V., Scutera, S., Gugliesi, F., Griffante, G., De Andrea, M., et al. (2018b). The Viral Tegument Protein pp65 Impairs Transcriptional Upregulation of IL-1 $\beta$ by Human Cytomegalovirus through Inhibition of NF-kB Activity. Viruses 10:567. doi: 10.3390/v10100567

Boeck, J. M., and Spencer, J. V. (2017). Effect of human cytomegalovirus (HCMV) US27 on CXCR4 receptor internalization measured by fluorogen-activating protein (FAP) biosensors. PLoS One 12:e0172042. doi: 10.1371/journal.pone. 0172042

Boeck, J. M., Stowell, G. A., O'Connor, C. M., and Spencer, J. V. (2018). The Human Cytomegalovirus US27 Gene Product Constitutively Activates Antioxidant Response Element-Mediated Transcription through G $\gamma$, Phosphoinositide 3Kinase, and Nuclear Respiratory Factor 1. J. Virol. 92:e0644-18. doi: 10.1128/ JVI.00644- 18

Bogdanow, B., Weisbach, H., von Einem, J., Straschewski, S., Voigt, S., Winkler, M., et al. (2013). Human cytomegalovirus tegument protein pp150 acts as a cyclin A2-CDK-dependent sensor of the host cell cycle and differentiation state. Proc. Natl. Acad. Sci. U.S.A. 110, 17510-17515. doi: 10.1073/pnas.1312235110

Boppana, S. B., and Britt, W. J. (1995). Antiviral antibody responses and intrauterine transmission after primary maternal cytomegalovirus infection. J. Infect. Dis. 171, 1115-1121. doi: 10.1093/infdis/171.5.1115

Borst, E. M., Bauerfeind, R., Binz, A., Stephan, T. M., Neuber, S., Wagner, K., et al. (2016). The essential human cytomegalovirus proteins pUL77 and pUL93 are structural components necessary for viral genome encapsidation. J. Virol. 90, 5860-5875. doi: 10.1128/jvi.00384- 16

Boyle, K. A., and Compton, T. (1998). Receptor-binding properties of a soluble form of human cytomegalovirus glycoprotein B. J. Virol. 72, 1826-1833. doi: 10.1128/jvi.72.3.1826-1833.1998
Bradley, A. J., Lurain, N. S., Ghazal, P., Trivedi, U., Cunningham, C., Baluchova, K., et al. (2009). High-throughput sequence analysis of variants of human cytomegalovirus strains Towne and AD169. J. Gen. Virol. 90(Pt 10), 2375-2380. doi: 10.1099/vir.0.013250-0

Brandariz-Nuñez, A., Liu, T., Du, T., and Evilevitch, A. (2019). Pressure-driven release of viral genome into a host nucleus is a mechanism leading to herpes infection. eLife 8:e47212. doi: 10.7554/eLife.47212

Bresnahan, W. A., Hultman, G. E., and Shenk, T. (2000). Replication of wild-type and mutant human cytomegalovirus in life-extended human diploid fibroblasts. J. Virol. 74, 10816-10818. doi: 10.1128/jvi.74.22.10816-10818.2000

Brock, I., Krüger, M., Mertens, T., and von Einem, J. (2013). Nuclear targeting of human cytomegalovirus large tegument protein pUL48 is essential for viral growth. J. Virol. 87, 6005-6019. doi: 10.1128/jvi.03558-12

Buchkovich, N. J., Maguire, T. G., and Alwine, J. C. (2010). Role of the endoplasmic reticulum chaperone BiP, SUN domain proteins, and dynein in altering nuclear morphology during human cytomegalovirus infection. J. Virol. 84, 7005-7017. doi: 10.1128/JVI.00719-10

Butcher, S. J., Aitken, J., Mitchell, J., Gowen, B., and Dargan, D. J. (1998). Structure of the human cytomegalovirus B capsid by electron cryomicroscopy and image reconstruction. J. Struct. Biol. 124, 70-76. doi: 10.1006/jsbi.1998.4055

Caffarelli, N., Fehr, A. R., and Yu, D. (2013). Cyclin A degradation by primate cytomegalovirus protein pUL21a counters its innate restriction of virus replication. PLoS Pathog. 9:e1003825. doi: 10.1371/journal.ppat.1003825

Caló, S., Cortese, M., Ciferri, C., Bruno, L., Gerrein, R., Benucci, B., et al. (2016). The Human Cytomegalovirus UL116 gene encodes an envelope glycoprotein forming a complex with gH Independently from gL. J. Virol. 90, 4926-4938. doi: 10.1128/JVI.02517-15

Cannon, M. J., Schmid, D. S., and Hyde, T. B. (2010). Review of cytomegalovirus seroprevalence and demographic characteristics associated with infection. Rev. Med. Virol. 20, 202-213. doi: 10.1002/rmv.655

Cantrell, S. R., and Bresnahan, W. A. (2006). Human cytomegalovirus (HCMV) UL82 gene product (pp71) relieves hDaxx-mediated repression of HCMV replication. J. Virol. 80, 6188-6191. doi: 10.1128/jvi.02676-05

Caposio, P., Riera, L., Hahn, G., Landolfo, S., and Gribaudo, G. (2004). Evidence that the human cytomegalovirus $46-\mathrm{kDa}$ UL72 protein is not an active dUTPase but a late protein dispensable for replication in fibroblasts. Virology 325, 264-276. doi: 10.1016/j.virol.2004.05.010

Cappadona, I., Villinger, C., Schutzius, G., Mertens, T., and von Einem, J. (2015). Human Cytomegalovirus pUL47 modulates tegumentation and capsid accumulation at the viral assembly complex. J. Virol. 89, 7314-7328. doi: 10. 1128/jvi.00603-15

Casarosa, P., Gruijthuijsen, Y. K., Michel, D., Beisser, P. S., Holl, J., Fitzsimons, C. P., et al. (2003). Constitutive signaling of the human cytomegalovirusencoded receptor UL33 differs from that of its rat cytomegalovirus homolog R33 by promiscuous activation of $\mathrm{G}$ proteins of the Gq. Gi, and Gs classes. J. Biol. Chem. 278, 50010-50023. doi: 10.1074/jbc.m306530200

Casavant, N. C., Luo, M. H., Rosenke, K., Winegardner, T., Zurawska, A., and Fortunato, E. A. (2006). Potential role for p53 in the permissive life cycle of human cytomegalovirus. J. Virol. 80, 8390-8401. doi: 10.1128/jvi.00505-06

Cha, T. A., Tom, E., Kemble, G. W., Duke, G. M., Mocarski, E. S., and Spaete, R. R. (1996). Human cytomegalovirus clinical isolates carry at least 19 genes not found in laboratory strains. J. Virol. 70, 78-83. doi: 10.1128/jvi.70.1.78-8 3.1996

Chan, G., Nogalski, M. T., Bentz, G. L., Smith, M. S., Parmater, A., and Yurochko, A. D. (2010). PI3K-dependent upregulation of Mcl-1 by human cytomegalovirus is mediated by epidermal growth factor receptor and inhibits apoptosis in short-lived monocytes. Jo. Immunol. 184, 3213-3222. doi: 10.4049/ jimmunol.0903025

Chemaly, R. F., Ullmann, A. J., Stoelben, S., Richard, M. P., Bornhäuser, M., Groth, C., et al. (2014). Letermovir for cytomegalovirus prophylaxis in hematopoietic-cell transplantation. N. Engl. J. Med. 370, 1781-1789. doi: 10. 1056/NEJMoa1309533

Chen, D. H., Jiang, H., Lee, M., Liu, F., and Zhou, Z. H. (1999). Threedimensional visualization of tegument/capsid interactions in the intact human cytomegalovirus. Virology 260, 10-16. doi: 10.1006/viro.1999.9791

Cheng, S., Caviness, K., Buehler, J., Smithey, M., Nikolich-Žugich, J., and Goodrum, F. (2017). Transcriptome-wide characterization of human cytomegalovirus in natural infection and experimental latency. Proc. Natl. Acad. Sci. U.S.A. 114, E10586-E10595. doi: 10.1073/pnas.1710522114 
Chevillotte, M., Schubert, A., Mertens, T., and von Einem, J. (2009). Fluorescencebased assay for phenotypic characterization of human cytomegalovirus polymerase mutations regarding drug susceptibility and viral replicative fitness. Antimicrob. Agents Chemother. 53, 3752-3761. doi: 10.1128/AAC.00165-09

Coaquette, A., Bourgeois, A., Dirand, C., Varin, A., Chen, W., and Herbein, G. (2004). Mixed cytomegalovirus glycoprotein B genotypes in immunocompromised patients. Clin. Infect. Dis. 39, 155-161. doi: $10.1086 / 421496$

Cocohoba, J. M., and McNicholl, I. R. (2002). Valganciclovir: an advance in cytomegalovirus therapeutics. Ann. Pharmacother. 36, 1075-1079. doi: 10.1345/ aph.1A393

Colletti, K. S., Xu, Y., Yamboliev, I., and Pari, G. S. (2005). Human cytomegalovirus UL84 is a phosphoprotein that exhibits UTPase activity and is a putative member of the DExD/H box family of proteins. J. Biol. Chem. 280, 1195511960. doi: 10.1074/jbc.C400603200

Compton, T., Nowlin, D. M., and Cooper, N. R. (1993). Initiation of human cytomegalovirus infection requires initial interaction with cell surface heparan sulfate. Virology 193, 834-841. doi: 10.1006/viro.1993.1192

Cortese, M., Calò, S., D’Aurizio, R., Lilja, A., Pacchiani, N., and Merola, M. (2012). Recombinant human cytomegalovirus (HCMV) RL13 binds human immunoglobulin G Fc. PLoS One 7:e50166. doi: 10.1371/journal.pone.0050166

Costa, H., Nascimento, R., Sinclair, J., and Parkhouse, R. M. E. (2013). Human cytomegalovirus gene UL76 induces IL-8 expression through activation of the DNA damage response. PLoS Pathog. 9:e1003609. doi: 10.1371/journal.ppat. 1003609

Cui, Z., Zhang, K., Zhang, Z., Liu, Y., Zhou, Y., Wei, H., et al. (2009). Visualization of the dynamic multimerization of human Cytomegalovirus pp65 in punctuate nuclear foci. Virology 392, 169-177. doi: 10.1016/j.virol.2009.06.021

Dal Monte, P., Pignatelli, S., Mach, M., and Landini, M. P. (2001). The product of human cytomegalovirus UL73 is a new polymorphic structural glycoprotein (gpUL73). J. Hum. Virol. 4, 26-34.

Dal Monte, P., Pignatelli, S., Zini, N., Maraldi, N. M., Perret, E., Prevost, M. C., et al. (2002). Analysis of intracellular and intraviral localization of the human cytomegalovirus UL53 protein. J. Gen. Virol. 83(Pt 5), 1005-1012. doi: 10.1099/ 0022-1317-83-5-1005

Dal Monte, P., Varani, S., Lazzarotto, T., Pignatelli, S., and Landini, M. P. (1998). Prokaryotic expression of human cytomegalovirus pUS22 and its reactivity with human antibody. Arch. Virol. 143, 2413-2419. doi: 10.1007/s007050050470

Das, S., Ortiz, D. A., Gurczynski, S. J., Khan, F., and Pellett, P. E. (2014). Identification of human cytomegalovirus genes important for biogenesis of the cytoplasmic virion assembly complex. J. Virol. 88, 9086-9099. doi: 10.1128/jvi. 01141-14

Davison, A. J., Dolan, A., Akter, P., Addison, C., Dargan, D. J., Alcendor, D. J., et al. (2003). The human cytomegalovirus genome revisited: comparison with the chimpanzee cytomegalovirus genome. J. Gen. Virol. 84(Pt 1), 17-28. doi: 10.1099/vir.0.18606-0

DeRussy, B. M., and Tandon, R. (2015). Human Cytomegalovirus pUL93 is required for viral genome cleavage and packaging. J. Virol. 89, 12221-12225. doi: 10.1128/jvi.02382-15

Dietz, A. N., Villinger, C., Becker, S., Frick, M., and von Einem, J. (2018). A Tyrosine-Based Trafficking Motif of the Tegument Protein pUL71 is crucial for human cytomegalovirus secondary envelopment. J. Virol. 92:e00907-17. doi: 10.1128/jvi.00907-17

Dolan, A., Cunningham, C., Hector, R. D., Hassan-Walker, A. F., Lee, L., Addison, C., et al. (2004). Genetic content of wild-type human cytomegalovirus. J. Gen. Virol. 85(Pt 5), 1301-1312. doi: 10.1099/vir.0.79888-0

Eifler, M., Uecker, R., Weisbach, H., Bogdanow, B., Richter, E., König, L., et al. (2014). PUL21a-Cyclin A2 interaction is required to protect human cytomegalovirus-infected cells from the deleterious consequences of mitotic entry. PLoS Pathog. 10:e1004514. doi: 10.1371/journal.ppat.1004514

Fang, W., Mori, T., and Cobrinik, D. (2002). Regulation of PML-dependent transcriptional repression by $\mathrm{pRB}$ and low penetrance $\mathrm{pRB}$ mutants. Oncogene 21, 5557-5565. doi: 10.1038/sj.onc. 1205666

Fehr, A. R., Gualberto, N. C., Savaryn, J. P., Terhune, S. S., and Yu, D. (2012). Proteasome-dependent disruption of the E3 ubiquitin ligase anaphasepromoting complex by HCMV protein pUL21a. PLoS Pathog. 8:e1002789. doi: 10.1371/journal.ppat.1002789

Feichtinger, S., Stamminger, T., Müller, R., Graf, L., Klebl, B., Eickhoff, J., et al. (2011). Recruitment of cyclin-dependent kinase 9 to nuclear compartments during cytomegalovirus late replication: importance of an interaction between viral pUL69 and cyclin T1. J. Gen. Virol. 92(Pt 7), 1519-1531. doi: 10.1099/vir. 0.030494-0

Feire, A. L., Koss, H., and Compton, T. (2004). Cellular integrins function as entry receptors for human cytomegalovirus via a highly conserved disintegrin-like domain. Proc. Natl. Acad. Sci. U.S.A. 101, 15470-15475. doi: 10.1073/pnas. 0406821101

Feng, L., Sheng, J., Vu, G. P., Liu, Y., Foo, C., Wu, S., et al. (2018). Human cytomegalovirus UL23 inhibits transcription of interferon- $\gamma$ stimulated genes and blocks antiviral interferon- $\gamma$ responses by interacting with human N-myc interactor protein. PLoS Pathog. 14:e1006867. doi: 10.1371/journal.ppat. 1006867

Feng, X., Schröer, J., Yu, D., and Shenk, T. (2006). Human cytomegalovirus pUS24 is a virion protein that functions very early in the replication cycle. J. Virol. 80, 8371-8378. doi: 10.1128/jvi.00399-06

Foglierini, M., Marcandalli, J., and Perez, L. (2019). HCMV envelope glycoprotein diversity demystified. Front. Microbiol. 10:1005. doi: 10.3389/fmicb.2019.01005

Fraile-Ramos, A., Pelchen-Matthews, A., Kledal, T. N., Browne, H., Schwartz, T. W., and Marsh, M. (2002). Localization of HCMV UL33 and US27 in endocytic compartments and viral membranes. Traffic 3, 218-232. doi: 10 . 1034/j.1600-0854.2002.030307.x

Frank, T., Niemann, I., Reichel, A., and Stamminger, T. (2019). Emerging roles of cytomegalovirus-encoded $\mathrm{G}$ protein-coupled receptors during lytic and latent infection. Med. Microbiol. Immunol. 208, 447-456. doi: 10.1007/s00430-01900595-9

Fries, B. C., Chou, S., Boeckh, M., and Torok-Storb, B. (1994). Frequency distribution of cytomegalovirus envelope glycoprotein genotypes in bone marrow transplant recipients. J. Infect. Dis. 169, 769-774. doi: 10.1093/infdis/ 169.4.769

Fu, Y.-Z., Su, S., Gao, Y.-Q., Wang, P.-P., Huang, Z.-F., Hu, M.-M., et al. (2017). Human cytomegalovirus tegument protein UL82 inhibits STING-mediated signaling to evade antiviral immunity. Cell Host Microbe 21, 231-243. doi: 10.1016/j.chom.2017.01.001

Fu, Y. Z., Su, S., Zou, H. M., Guo, Y., Wang, S. Y., Li, S., et al. (2019). Human cytomegalovirus DNA polymerase subunit UL44 antagonizes antiviral immune responses by suppressing IRF3- and NF-кB-mediated transcription. J. Virol. 93:e00181-19. doi: 10.1128/jvi.00181-19

Gao, J. L., and Murphy, P. M. (1994). Human cytomegalovirus open reading frame US28 encodes a functional beta chemokine receptor. J. Biol. Chem. 269, 28539-28542.

Gao, Y., Kagele, D., Smallenberg, K., and Pari, G. S. (2010). Nucleocytoplasmic shuttling of human cytomegalovirus UL84 is essential for virus growth. J. Virol. 84, 8484-8494. doi: 10.1128/jvi.00738-10

Gao, Y., and Pari, G. S. (2009). Interaction of human cytomegalovirus pUL84 with casein kinase 2 is required for oriLyt-dependent DNA replication. J. Virol. 83, 2393-2396. doi: 10.1128/JVI.02339-08

Gebert, S., Schmolke, S., Sorg, G., Flöss, S., Plachter, B., and Stamminger, T. (1997). The UL84 protein of human cytomegalovirus acts as a transdominant inhibitor of immediate-early-mediated transactivation that is able to prevent viral replication. J. Virol. 71, 7048-7060. doi: 10.1128/jvi.71.9.7048-7060.1997

Gerna, G., Percivalle, E., Lilleri, D., Lozza, L., Fornara, C., Hahn, G., et al. (2005). Dendritic-cell infection by human cytomegalovirus is restricted to strains carrying functional UL131-128 genes and mediates efficient viral antigen presentation to CD8 ${ }^{+}$T cells. J. Gen. Virol. 86(Pt 2), 275-284. doi: 10.1099/vir. 0.80474-0

Gibson, W., Baxter, M. K., and Clopper, K. S. (1996a). Cytomegalovirus "missing” capsid protein identified as heat-aggregable product of human cytomegalovirus UL46. J. Virol. 70, 7454-7461. doi: 10.1128/jvi.70.11.7454-7461.1996

Gibson, W., Clopper, K. S., Britt, W. J., and Baxter, M. K. (1996b). Human cytomegalovirus (HCMV) smallest capsid protein identified as product of short open reading frame located between HCMV UL48 and UL49. J. Virol. 70, 5680-5683. doi: 10.1128/jvi.70.8.5680-5683.1996

Glass, M., and Everett, R. D. (2013). Components of promyelocytic leukemia nuclear bodies (ND10) act cooperatively to repress herpesvirus infection. J. Virol. 87, 2174-2185. doi: 10.1128/JVI.02950-12

Goldberg, M. D., Honigman, A., Weinstein, J., Chou, S., Taraboulos, A., Rouvinski, A., et al. (2011). Human cytomegalovirus UL97 kinase and nonkinase functions mediate viral cytoplasmic secondary envelopment. J. Virol. 85, 3375-3384. doi: 10.1128/jvi.01952-10 
Gopal, S., Perez, E., Xia, A. Y., Knowlton, J. J., Cerqueira, F., Dermody, T. S., et al. (2018). Murine cytomegalovirus M72 promotes acute virus replication in vivo and is a substrate of the TRiC/CCT complex. Virology 522, 92-105. doi: 10.1016/j.virol.2018.07.008

Graf, L., Feichtinger, S., Naing, Z., Hutterer, C., Milbradt, J., Webel, R., et al. (2016). New insight into the phosphorylation-regulated intranuclear localization of human cytomegalovirus pUL69 mediated by cyclin-dependent kinases (CDKs) and viral CDK orthologue pUL97. J. Gen. Virol. 97, 144-151. doi: 10.1099/jgv.0. 000337

Greijer, A. E., Dekkers, C. A., and Middeldorp, J. M. (2000). Human cytomegalovirus virions differentially incorporate viral and host cell RNA during the assembly process. J. Virol. 74, 9078-9082. doi: 10.1128/jvi.74.19. 9078-9082.2000

Griffiths, P. D., Stanton, A., McCarrell, E., Smith, C., Osman, M., Harber, M., et al. (2011). Cytomegalovirus glycoprotein-B vaccine with MF59 adjuvant in transplant recipients: a phase 2 randomised placebo-controlled trial. Lancet 377, 1256-1263. doi: 10.1016/S0140-6736(11)60136-0

Hage, E., Wilkie, G. S., Linnenweber-Held, S., Dhingra, A., Suarez, N. M., Schmidt, J. J., et al. (2017). Characterization of human cytomegalovirus genome diversity in immunocompromised hosts by whole-genome sequencing directly from clinical specimens. J. Infect. Dis. 215, 1673-1683. doi: 10.1093/infdis/jix157

Hahn, G., Khan, H., Baldanti, F., Koszinowski, U. H., Revello, M. G., and Gerna, G. (2002). The human cytomegalovirus ribonucleotide reductase homolog UL45 is dispensable for growth in endothelial cells, as determined by a BACcloned clinical isolate of human cytomegalovirus with preserved wild-type characteristics. J. Virol. 76, 9551-9555. doi: 10.1128/jvi.76.18.9551-9555.2002

Hamilton, S. T., Milbradt, J., Marschall, M., and Rawlinson, W. D. (2014). Human cytomegalovirus replication is strictly inhibited by siRNAs targeting UL54, UL97 or UL122/123 gene transcripts. PLoS One 9:e97231. doi: 10.1371/journal. pone.0097231

Hayashi, M. L., Blankenship, C., and Shenk, T. (2000). Human cytomegalovirus UL69 protein is required for efficient accumulation of infected cells in the G1 phase of the cell cycle. Proc. Natl. Acad. Sci. U.S.A. 97, 2692-2696. doi: 10.1073/pnas.050587597

Hayes, K., Danks, D. M., Gibas, H., and Jack, I. (1972). Cytomegalovirus in human milk. N. Engl. J. Med. 287, 177-178.

Hobom, U., Brune, W., Messerle, M., Hahn, G., and Koszinowski, U. H. (2000). Fast screening procedures for random transposon libraries of cloned herpesvirus genomes: mutational analysis of human cytomegalovirus envelope glycoprotein genes. J. Virol. 74, 7720-7729. doi: 10.1128/jvi.74.17.7720-7729.2000

Hofmann, H., Sindre, H., and Stamminger, T. (2002). Functional interaction between the pp71 protein of human cytomegalovirus and the PML-interacting protein human Daxx. J. Virol. 76, 5769-5783. doi: 10.1128/jvi.76.11.5769-5783. 2002

Hollenbach, A. D., McPherson, C. J., Mientjes, E. J., Iyengar, R., and Grosveld, G. (2002). Daxx and histone deacetylase II associate with chromatin through an interaction with core histones and the chromatin-associated protein Dek. J. Cell Sci. 115(Pt 16), 3319-3330.

Huber, M. T., and Compton, T. (1998). The human cytomegalovirus UL74 gene encodes the third component of the glycoprotein H-glycoprotein L-containing envelope complex. J. Virol. 72, 8191-8197. doi: 10.1128/jvi.72.10.8191-8197. 1998

Huber, M. T., and Compton, T. (1999). Intracellular formation and processing of the heterotrimeric gH-gL-gO (gCIII) glycoprotein envelope complex of human cytomegalovirus. J. Virol. 73, 3886-3892. doi: 10.1128/jvi.73.5.3886-3892.1999

Hume, A. J., Finkel, J. S., Kamil, J. P., Coen, D. M., Culbertson, M. R., and Kalejta, R. F. (2008). Phosphorylation of retinoblastoma protein by viral protein with cyclin-dependent kinase function. Science 320, 797-799. doi: 10.1126/science. 1152095

Hwang, J., and Kalejta, R. F. (2007). Proteasome-dependent, ubiquitinindependent degradation of Daxx by the viral pp71 protein in human cytomegalovirus-infected cells. Virology 367, 334-338. doi: 10.1016/j.virol. 2007.05.037

Hwang, J., and Kalejta, R. F. (2009). Human cytomegalovirus protein pp71 induces Daxx SUMOylation. J. Virol. 83, 6591-6598. doi: 10.1128/JVI.02639-08

Hyun, J. J., Park, H. S., Kim, K. H., and Kim, H. J. (1999). Analysis of transcripts expressed from the UL47 gene of human cytomegalovirus. Arch. Pharm. Res. 22, 542-548. doi: 10.1007/bf02975323
Indran, S. V., Ballestas, M. E., and Britt, W. J. (2010). Bicaudal D1-dependent trafficking of human cytomegalovirus tegument protein pp150 in virus-infected cells. J. Virol. 84, 3162-3177. doi: 10.1128/jvi.01776-09

Irmiere, A., and Gibson, W. (1983). Isolation and characterization of a noninfectious virion-like particle released from cells infected with human strains of cytomegalovirus. Virology 130, 118-133. doi: 10.1016/0042-6822(83) 90122-8

Isaacson, M. K., and Compton, T. (2009). Human cytomegalovirus glycoprotein B is required for virus entry and cell-to-cell spread but not for virion attachment, assembly, or egress. J. Virol. 83, 3891-3903. doi: 10.1128/JVI.01251-08

Isaacson, M. K., Feire, A. L., and Compton, T. (2007). Epidermal growth factor receptor is not required for human cytomegalovirus entry or signaling. J. Virol. 81, 6241-6247. doi: 10.1128/jvi.00169-07

Ishov, A. M., and Maul, G. G. (1996). The periphery of nuclear domain 10 (ND10) as site of DNA virus deposition. J. Cell Biol. 134, 815-826. doi: 10.1083/jcb.134. 4.815

Ishov, A. M., Sotnikov, A. G., Negorev, D., Vladimirova, O. V., Neff, N., Kamitani, T., et al. (1999). PML is critical for ND10 formation and recruits the PMLinteracting protein daxx to this nuclear structure when modified by SUMO-1. J. Cell Biol. 147, 221-234. doi: 10.1083/jcb.147.2.221

Ishov, A. M., Stenberg, R. M., and Maul, G. G. (1997). Human cytomegalovirus immediate early interaction with host nuclear structures: definition of an immediate transcript environment. J. Cell Biol. 138, 5-16. doi: 10.1083/jcb.1 38.1 .5

Ishov, A. M., Vladimirova, O. V., and Maul, G. G. (2002). Daxx-mediated accumulation of human cytomegalovirus tegument protein pp71 at ND10 facilitates initiation of viral infection at these nuclear domains. J. Virol. 76, 7705-7712. doi: 10.1128/jvi.76.15.7705-7712.2002

Iskenderian, A. C., Huang, L., Reilly, A., Stenberg, R. M., and Anders, D. G. (1996). Four of eleven loci required for transient complementation of human cytomegalovirus DNA replication cooperate to activate expression of replication genes. J. Virol. 70, 383-392. doi: 10.1128/jvi.70.1.383-392.1996

Isomura, H., Stinski, M. F., Kudoh, A., Murata, T., Nakayama, S., Sato, Y., et al. (2008). Noncanonical TATA sequence in the UL44 late promoter of human cytomegalovirus is required for the accumulation of late viral transcripts. J. Virol. 82, 1638-1646. doi: 10.1128/jvi.01917-07

Isomura, H., Stinski, M. F., Murata, T., Nakayama, S., Chiba, S., Akatsuka, Y., et al. (2010). The human cytomegalovirus UL76 gene regulates the level of expression of the UL77 gene. PLoS One 5:e11901. doi: 10.1371/journal.pone.0011901

Isomura, H., Stinski, M. F., Murata, T., Yamashita, Y., Kanda, T., Toyokuni, S., et al. (2011). The human cytomegalovirus gene products essential for late viral gene expression assemble into prereplication complexes before viral DNA replication. J. Virol. 85, 6629-6644. doi: 10.1128/jvi.00384-11

Iwahori, S., Hakki, M., Chou, S., and Kalejta, R. F. (2015). Molecular Determinants for the Inactivation of the Retinoblastoma Tumor Suppressor by the Viral Cyclin-dependent Kinase UL97. J. Biol. Chem. 290, 19666-19680. doi: 10.1074/ jbc.M115.660043

Iwahori, S., and Kalejta, R. F. (2017). Phosphorylation of transcriptional regulators in the retinoblastoma protein pathway by UL97, the viral cyclin-dependent kinase encoded by human cytomegalovirus. Virology 512, 95-103. doi: 10.1016/ j.virol.2017.09.009

Iwahori, S., Umaña, A. C., VanDeusen, H. R., and Kalejta, R. F. (2017). Human cytomegalovirus-encoded viral cyclin-dependent kinase (v-CDK) UL97 phosphorylates and inactivates the retinoblastoma protein-related p107 and p130 proteins. J. Biol. Chem. 292, 6583-6599. doi: 10.1074/jbc.M116. 773150

Jiang, X. J., Sampaio, K. L., Ettischer, N., Stierhof, Y.-D., Jahn, G., Kropff, B., et al. (2011). UL74 of human cytomegalovirus reduces the inhibitory effect of gHspecific and gB-specific antibodies. Arch. Virol. 156, 2145-2155. doi: 10.1007/ s00705-011-1105- $\mathrm{x}$

Jiang, X.-J., Zhang, J., Xiong, Y., Jahn, G., Xiong, H.-R., Yang, Z.-Q., et al. (2017). Human cytomegalovirus glycoprotein polymorphisms and increasing viral load in AIDS patients. PLoS One 12:e0176160. doi: 10.1371/journal.pone.01 76160

Kagele, D., Gao, Y., Smallenburg, K., and Pari, G. S. (2009). Interaction of HCMV UL84 with C/EBPalpha transcription factor binding sites within oriLyt is essential for lytic DNA replication. Virology 392, 16-23. doi: 10.1016/j.virol. 2009.06.035 
Kalejta, R. F., and Shenk, T. (2003). Proteasome-dependent, ubiquitin-independent degradation of the $\mathrm{Rb}$ family of tumor suppressors by the human cytomegalovirus pp71 protein. Proc. Natl. Acad. Sci. U.S.A. 100, 3263-3268. doi: $10.1073 /$ pnas. 0538058100

Kari, B., and Gehrz, R. (1992). A human cytomegalovirus glycoprotein complex designated gC-II is a major heparin-binding component of the envelope. J. Virol. 66, 1761-1764. doi: 10.1128/jvi.66.3.1761-1764.1992

Kerry, J. A., Priddy, M. A., Staley, T. L., Jones, T. R., and Stenberg, R. M. (1997). The role of ATF in regulating the human cytomegalovirus DNA polymerase (UL54) promoter during viral infection. J. Virol. 71, 2120-2126. doi: 10.1128/jvi.71.3. 2120-2126.1997

Kerry, J. A., Priddy, M. A., and Stenberg, R. M. (1994). Identification of sequence elements in the human cytomegalovirus DNA polymerase gene promoter required for activation by viral gene products. J. Virol. 68, 4167-4176. doi: 10.1128/jvi.68.7.4167-4176.1994

Keyvani, H., Taghinezhad Saroukalaei, S., and Mohseni, A. H. (2016). Assessment of the Human Cytomegalovirus UL97 gene for identification of resistance to Ganciclovir in Iranian immunosuppressed patients. Jundishapur J. Microbiol. 9:e31733. doi: 10.5812/jjm.31733

Khaiboullina, S. F., Maciejewski, J. P., Crapnell, K., Spallone, P. A., Dean Stock, A., Pari, G. S., et al. (2004). Human cytomegalovirus persists in myeloid progenitors and is passed to the myeloid progeny in a latent form. Br. J. Haematol. 126, 410-417. doi: 10.1111/j.1365-2141.2004.05056.x

Kiehl, A., Huang, L., Franchi, D., and Anders, D. G. (2003). Multiple 5' ends of human cytomegalovirus UL57 transcripts identify a complex, cycloheximideresistant promoter region that activates oriLyt. Virology 314, 410-422. doi: 10.1016/s0042-6822(03)00438-0

Kim, J. H., Collins-McMillen, D., Buehler, J. C., Goodrum, F. D., and Yurochko, A. D. (2017). Human Cytomegalovirus requires epidermal growth factor receptor signaling to enter and initiate the early steps in the establishment of latency in CD34 human progenitor cells. J. Virol. 91:e01206-16. doi: 10.1128/ JVI.01206-16

Kim, Y. E., Oh, S. E., Kwon, K. M., Lee, C. H., and Ahn, J. H. (2016). Involvement of the N-Terminal Deubiquitinating protease domain of human cytomegalovirus UL48 tegument protein in autoubiquitination. virion stability, and virus entry. J. Virol. 90, 3229-3242. doi: 10.1128/jvi.02766-15

Kim, Y. J., Kim, E. T., Kim, Y. E., Lee, M. K., Kwon, K. M., Kim, K. I., et al. (2016). Consecutive Inhibition of ISG15 Expression and ISGylation by Cytomegalovirus Regulators. PLoS Pathog. 12:e1005850. doi: 10.1371/journal. ppat. 1005850

Kinzler, E. R., Theiler, R. N., and Compton, T. (2002). Expression and reconstitution of the $\mathrm{gH} / \mathrm{gL} / \mathrm{gO}$ complex of human cytomegalovirus. J. Clin. Virol. 25(Suppl. 2), S87-S95.

Kledal, T. N., Rosenkilde, M. M., and Schwartz, T. W. (1998). Selective recognition of the membrane-bound $\mathrm{CX} 3 \mathrm{C}$ chemokine, fractalkine, by the human cytomegalovirus-encoded broad-spectrum receptor US28. FEBS Lett. 441, 209-214. doi: 10.1016/s0014-5793(98)01551-8

Köppen-Rung, P., Dittmer, A., and Bogner, E. (2016). Intracellular Distribution of Capsid-Associated pUL77 of human cytomegalovirus and interactions with packaging proteins and pUL93. J. Virol. 90, 5876-5885. doi: 10.1128/JVI.00 351-16

Korioth, F., Maul, G. G., Plachter, B., Stamminger, T., and Frey, J. (1996). The nuclear domain $10(\mathrm{ND} 10)$ is disrupted by the human cytomegalovirus gene product IE1. Exp. Cell Res. 229, 155-158. doi: 10.1006/excr.1996.0353

Krishna, B. A., Miller, W. E., and O'Connor, C. M. (2018). US28: HCMV's swiss army knife. Viruses 10:445. doi: 10.3390/v10080445

Krishna, B. A., Poole, E. L., Jackson, S. E., Smit, M. J., Wills, M. R., and Sinclair, J. H. (2017a). Latency-associated expression of human Cytomegalovirus US28 attenuates cell signaling pathways to maintain latent infection. mBio 8:e0175417. doi: $10.1128 / \mathrm{mBio} .01754-17$

Krishna, B. A., Spiess, K., Poole, E. L., Lau, B., Voigt, S., Kledal, T. N., et al. (2017b). Targeting the latent cytomegalovirus reservoir with an antiviral fusion toxin protein. Nat. Commun. 8:14321. doi: 10.1038/ncomms14321

Kropff, B., Koedel, Y., Britt, W., and Mach, M. (2010). Optimal replication of human cytomegalovirus correlates with endocytosis of glycoprotein gpUL132. J. Virol. 84, 7039-7052. doi: 10.1128/JVI.01644-09

Kuan, M. I., O'Dowd, J. M., and Fortunato, E. A. (2016). The absence of p53 during Human Cytomegalovirus infection leads to decreased UL53 expression, disrupting UL50 localization to the inner nuclear membrane, and thereby inhibiting capsid nuclear egress. Virology 497, 262-278. doi: 10.1016/j.virol. 2016.07.020

Kwon, K. M., Oh, S. E., Kim, Y. E., Han, T. H., and Ahn, J. H. (2017). Cooperative inhibition of RIP1-mediated NF- $\mathrm{KB}$ signaling by cytomegalovirus-encoded deubiquitinase and inactive homolog of cellular ribonucleotide reductase large subunit. PLoS Pathog. 13:e1006423. doi: 10.1371/journal.ppat.1006423

Kwon, Y., Kim, M. N., Young Choi, E., Heon Kim, J., Hwang, E. S., and Cha, C. Y. (2012). Inhibition of p53 transcriptional activity by human cytomegalovirus UL44. Microbiol. Immunol. 56, 324-331. doi: 10.1111/j.1348-0421.2012.00 446.x

Lares, A. P., Tu, C. C., and Spencer, J. V. (2013). The human cytomegalovirus US27 gene product enhances cell proliferation and alters cellular gene expression. Virus Res. 176, 312-320. doi: 10.1016/j.virusres.2013.07.002

Leach, F. S., and Mocarski, E. S. (1989). Regulation of cytomegalovirus late-gene expression: differential use of three start sites in the transcriptional activation of ICP36 gene expression. J. Virol. 63, 1783-1791. doi: 10.1128/jvi.63.4.17831791.1989

Lee, J.-H., and Kalejta, R. F. (2019). Human cytomegalovirus enters the primary CD34 hematopoietic progenitor cells where it establishes latency by macropinocytosis. J. Virol. 93:e00452-19. doi: 10.1128/JVI.00452-19

Lewis, P. W., Elsaesser, S. J., Noh, K.-M., Stadler, S. C., and Allis, C. D. (2010). Daxx is an H3.3-specific histone chaperone and cooperates with ATRX in replicationindependent chromatin assembly at telomeres. Proc. Natl. Acad. Sci. U.S.A. 107, 14075-14080. doi: 10.1073/pnas.1008850107

Li, G., Rak, M., Nguyen, C. C., Umashankar, M., Goodrum, F. D., and Kamil, J. P. (2014). An epistatic relationship between the viral protein kinase UL97 and the UL133-UL138 latency locus during the human cytomegalovirus lytic cycle. J. Virol. 88, 6047-6060. doi: 10.1128/jvi.00447-14

Li, M., Ma, Y., Ji, Y., He, R., Qi, Y., Sun, Z., et al. (2011). Human cytomegalovirus RL13 gene transcripts in a clinical strain. Virus Genes 43, 327-334. doi: 10.1007/ s11262-011-0641-5

Li, T., Chen, J., and Cristea, I. M. (2013). Human cytomegalovirus tegument protein pUL83 inhibits IFI16-mediated DNA sensing for immune evasion. Cell Host Microbe 14, 591-599. doi: 10.1016/j.chom.2013.10.007

Li, W., Eidman, K., Gehrz, R. C., and Kari, B. (1995). Identification and molecular characterization of the murine cytomegalovirus homolog of the human cytomegalovirus UL100 gene. Virus Res. 36, 163-175. doi: 10.1016/ 0168-1702(94)00117-u

Ligat, G., Cazal, R., Hantz, S., and Alain, S. (2018). The human cytomegalovirus terminase complex as an antiviral target: a close-up view. FEMS Microbiol. Rev. 42, 137-145. doi: 10.1093/femsre/fuy004

Lischka, P., Toth, Z., Thomas, M., Mueller, R., and Stamminger, T. (2006). The UL69 transactivator protein of human cytomegalovirus interacts with DEXD/H-Box RNA helicase UAP56 to promote cytoplasmic accumulation of unspliced RNA. Mol. Cell. Biol. 26, 1631-1643. doi: 10.1128/mcb.26.5.16311643.2006

Liu, J., Kong, J., Chang, Y. J., Chen, H., Chen, Y. H., Han, W., et al. (2015). Patients with refractory cytomegalovirus (CMV) infection following allogeneic haematopoietic stem cell transplantation are at high risk for CMV disease and non-relapse mortality. Clin. Microbiol. Infect. 21:1121.e9-15. doi: 10.1016/j.cmi. 2015.06.009

Liu, Y., and Biegalke, B. J. (2002). The human cytomegalovirus UL35 gene encodes two proteins with different functions. J. Virol. 76, 2460-2468. doi: 10.1128/jvi. 76.5.2460-2468.2002

Liu, Y., Cui, Z., Zhang, Z., Wei, H., Zhou, Y., Wang, M., et al. (2009). The tegument protein UL94 of human cytomegalovirus as a binding partner for tegument protein pp28 identified by intracellular imaging. Virology 388, 68-77. doi: 10.1016/j.virol.2009.03.007

Loregian, A., Rigatti, R., Murphy, M., Schievano, E., Palu, G., and Marsden, H. S. (2003). Inhibition of human cytomegalovirus DNA polymerase by C-terminal peptides from the UL54 subunit. J. Virol. 77, 8336-8344. doi: 10.1128/jvi.77.15. 8336-8344.2003

Lorz, K., Hofmann, H., Berndt, A., Tavalai, N., Mueller, R., Schlötzer-Schrehardt, U., et al. (2006). Deletion of open reading frame UL26 from the human cytomegalovirus genome results in reduced viral growth, which involves impaired stability of viral particles. J. Virol. 80, 5423-5434. doi: 10.1128/jvi. 02585-05 
Lu, M., and Shenk, T. (1999). Human cytomegalovirus UL69 protein induces cells to accumulate in G1 phase of the cell cycle. J. Virol. 73, 676-683. doi: 10.1128/jvi.73.1.676-683.1999

Lye, M. F., Sharma, M., El Omari, K., Filman, D. J., Schuermann, J. P., Hogle, J. M., et al. (2015). Unexpected features and mechanism of heterodimer formation of a herpesvirus nuclear egress complex. EMBO J. 34, 2937-2952. doi: 10.15252/ embj.201592651

Lyons, P. A., Dallas, P. B., Carrello, C., Shellam, G. R., and Scalzo, A. A. (1994). Mapping and transcriptional analysis of the murine cytomegalovirus homologue of the human cytomegalovirus UL103 open reading frame. Virology 204, 835-839. doi: 10.1006/viro.1994.1603

Mach, M., Kropff, B., Dal Monte, P., and Britt, W. (2000). Complex formation by human cytomegalovirus glycoproteins M (gpUL100) and N (gpUL73). J. Virol. 74, 11881-11892. doi: 10.1128/jvi.74.24.11881-11892.2000

Mach, M., Kropff, B., Kryzaniak, M., and Britt, W. (2005). Complex formation by glycoproteins $\mathrm{M}$ and $\mathrm{N}$ of human cytomegalovirus: structural and functional aspects. J. Virol. 79, 2160-2170. doi: 10.1128/jvi.79.4.2160-2170.2005

Maertens, J., Cordonnier, C., Jaksch, P., Poiré, X., Uknis, M., Wu, J., et al. (2019). Maribavir for preemptive treatment of cytomegalovirus reactivation. N. Engl. J. Med. 381, 1136-1147. doi: 10.1056/NEJMoa1714656

Manuel, O., Asberg, A., Pang, X., Rollag, H., Emery, V. C., Preiksaitis, J. K., et al. (2009). Impact of genetic polymorphisms in cytomegalovirus glycoprotein B on outcomes in solid-organ transplant recipients with cytomegalovirus disease. Clin. Infect. Dis. 49, 1160-1166. doi: 10.1086/605633

Marshall, E. E., Bierle, C. J., Brune, W., and Geballe, A. P. (2009). Essential role for either TRS1 or IRS1 in human cytomegalovirus replication. J. Virol. 83, 4112-4120. doi: 10.1128/jvi.02489-08

Marty, F. M., Winston, D. J., Chemaly, R. F., Mullane, K. M., Shore, T. B., Papanicolaou, G. A., et al. (2019). A randomized, double-blind, placebocontrolled phase 3 trial of oral brincidofovir for cytomegalovirus prophylaxis in allogeneic hematopoietic cell transplantation. Biol. Blood Marrow Trans. 25, 369-381. doi: 10.1016/j.bbmt.2018.09.038

Maschkowitz, G., Gärtner, S., Hofmann-Winkler, H., Fickenscher, H., and Winkler, M. (2018). Interaction of Human Cytomegalovirus Tegument Proteins ppUL35 and ppUL35A with Sorting Nexin 5 Regulates Glycoprotein B (gpUL55) Localization. J. Virol. 92:e00013-18. doi: 10.1128/JVI.00013-18

Matthews, T., and Boehme, R. (1988). Antiviral activity and mechanism of action of ganciclovir. Rev. Infect. Dis. 10(Suppl. 3), S490-S494. doi: 10.1093/clinids/10. supplement_3.s490

Maul, G. G. (2008). Initiation of cytomegalovirus infection at ND10. Curr. Top. Microbiol. Immunol. 325, 117-132. doi: 10.1007/978-3-540-77349-8_7

McCormick, A. L., Roback, L., Livingston-Rosanoff, D., and St Clair, C. (2010). The human cytomegalovirus UL36 gene controls caspase-dependent and -independent cell death programs activated by infection of monocytes differentiating to macrophages. J. Virol. 84, 5108-5123. doi: 10.1128/jvi.01 345-09

McKinney, C., Perez, C., and Mohr, I. (2012). Poly(A) binding protein abundance regulates eukaryotic translation initiation factor $4 \mathrm{~F}$ assembly in human cytomegalovirus-infected cells. Proc. Natl. Acad. Sci. U.S.A. 109, 5627-5632. doi: $10.1073 /$ pnas. 1202829109

Meissner, C. S., Köppen-Rung, P., Dittmer, A., Lapp, S., and Bogner, E. (2011). A "coiled-coil" motif is important for oligomerization and DNA binding properties of human cytomegalovirus protein UL77. PLoS One 6:e25115. doi: 10.1371/journal.pone.0025115

Meissner, C. S., Suffner, S., Schauflinger, M., von Einem, J., and Bogner, E. (2012). A leucine zipper motif of a tegument protein triggers final envelopment of human cytomegalovirus. J. Virol. 86, 3370-3382. doi: 10.1128/jvi.06556-11

Mendelson, M., Monard, S., Sissons, P., and Sinclair, J. (1996). Detection of endogenous human cytomegalovirus in $\mathrm{CD} 34^{+}$bone marrow progenitors. J. Gen. Virol. 77(Pt 12), 3099-3102. doi: 10.1099/0022-1317-77-12-3099

Mettenleiter, T. C. (2002). Herpesvirus assembly and egress. J. Virol. 76, 1537-1547. doi: 10.1128/jvi.76.4.1537-1547.2002

Michel, D., Milotić, I., Wagner, M., Vaida, B., Holl, J., Ansorge, R., et al. (2005). The human cytomegalovirus UL78 gene is highly conserved among clinical isolates, but is dispensable for replication in fibroblasts and a renal artery organ-culture system. J. Gen. Virol. 86(Pt 2), 297-306. doi: 10.1099/vir.0.80436-0

Michel, D., Pavić, I., Zimmermann, A., Haupt, E., Wunderlich, K., Heuschmid, M., et al. (1996). The UL97 gene product of human cytomegalovirus is an early-late protein with a nuclear localization but is not a nucleoside kinase. J. Virol. 70, 6340-6346. doi: 10.1128/jvi.70.9.6340-6346.1996

Mohammad, A. A., Costa, H., Landázuri, N., Lui, W. O., Hultenby, K., Rahbar, A., et al. (2017). Human cytomegalovirus microRNAs are carried by virions and dense bodies and are delivered to target cells. J. Gen. Virol. 98, 1058-1072. doi: 10.1099/jgv.0.000736

Moorman, N. J., Cristea, I. M., Terhune, S. S., Rout, M. P., Chait, B. T., and Shenk, T. (2008). Human cytomegalovirus protein UL38 inhibits host cell stress responses by antagonizing the tuberous sclerosis protein complex. Cell Host Microbe 3, 253-262. doi: 10.1016/j.chom.2008.03.002

Munger, J., Yu, D., and Shenk, T. (2006). UL26-deficient human cytomegalovirus produces virions with hypophosphorylated pp28 tegument protein that is unstable within newly infected cells. J. Virol. 80, 3541-3548. doi: 10.1128/jvi. 80.7.3541-3548.2006

Murata, H., Nii, R., Ito, M., Ihara, T., and Komada, Y. (2009). Quantitative detection of HCMV-DNA in saliva from infants and breast milk on real-time polymerase chain reaction. Pediatr. Int. 51, 530-534. doi: 10.1111/j.1442-200X. 2009.02814.x

Nogalski, M. T., Chan, G. C. T., Stevenson, E. V., Collins-McMillen, D. K., and Yurochko, A. D. (2013). The HCMV gH/gL/UL128-131 complex triggers the specific cellular activation required for efficient viral internalization into target monocytes. PLoS Pathog. 9:e1003463. doi: 10.1371/journal.ppat.1003463

Novak, Z., Ross, S. A., Patro, R. K., Pati, S. K., Kumbla, R. A., Brice, S., et al. (2008). Cytomegalovirus strain diversity in seropositive women. J. Clin. Microbiol. 46, 882-886. doi: 10.1128/JCM.01079-07

O'Connor, C. M., and Shenk, T. (2012). Human cytomegalovirus pUL78 G proteincoupled receptor homologue is required for timely cell entry in epithelial cells but not fibroblasts. J. Virol. 86, 11425-11433. doi: 10.1128/JVI.05900-11

Oduro, J. D., Uecker, R., Hagemeier, C., and Wiebusch, L. (2012). Inhibition of human cytomegalovirus immediate-early gene expression by cyclin A2dependent kinase activity. J. Virol. 86, 9369-9383. doi: 10.1128/jvi.07181-11

Pass, R. F., Zhang, C., Evans, A., Simpson, T., Andrews, W., Huang, M.-L., et al. (2009). Vaccine prevention of maternal cytomegalovirus infection. N. Engl. J. Med. 360, 1191-1199. doi: 10.1056/NEJMoa0804749

Paterson, D. A., Dyer, A. P., Milne, R. S. B., Sevilla-Reyes, E., and Gompels, U. A. (2002). A role for human cytomegalovirus glycoprotein $\mathrm{O}(\mathrm{gO})$ in cell fusion and a new hypervariable locus. Virology 293, 281-294.

Patrone, M., Percivalle, E., Secchi, M., Fiorina, L., Pedrali-Noy, G., Zoppé, M., et al. (2003). The human cytomegalovirus UL45 gene product is a late, virionassociated protein and influences virus growth at low multiplicities of infection. J. Gen. Virol. 84(Pt 12), 3359-3370. doi: 10.1099/vir.0.19452-0

Penkert, R. R., and Kalejta, R. F. (2010). Nuclear localization of tegument-delivered pp71 in human cytomegalovirus-infected cells is facilitated by one or more factors present in terminally differentiated fibroblasts. J. Virol. 84, 9853-9863. doi: 10.1128/JVI.00500-10

Pepperl, S., Münster, J., Mach, M., Harris, J. R., and Plachter, B. (2000). Dense bodies of human cytomegalovirus induce both humoral and cellular immune responses in the absence of viral gene expression. J. Virol. 74, 6132-6146. doi: 10.1128/jvi.74.13.6132-6146.2000

Perng, Y.-C., Qian, Z., Fehr, A. R., Xuan, B., and Yu, D. (2011a). The human cytomegalovirus gene UL79 is required for the accumulation of late viral transcripts. J. Virol. 85, 4841-4852. doi: 10.1128/JVI.02344-10

Perng, Y. C., Qian, Z., Fehr, A. R., Xuan, B., and Yu, D. (2011b). The human cytomegalovirus gene UL79 is required for the accumulation of late viral transcripts. J. Virol. 85, 4841-4852. doi: 10.1128/jvi.02344-10

Phillips, S. L., and Bresnahan, W. A. (2012). The human cytomegalovirus (HCMV) tegument protein UL94 is essential for secondary envelopment of HCMV virions. J. Virol. 86, 2523-2532. doi: 10.1128/JVI.06548-11

Phillips, S. L., Cygnar, D., Thomas, A., and Bresnahan, W. A. (2012). Interaction between the human cytomegalovirus tegument proteins UL94 and UL99 is essential for virus replication. J. Virol. 86, 9995-10005. doi: 10.1128/jvi.01 078-12

Poole, E. L., Kew, V. G., Lau, J. C. H., Murray, M. J., Stamminger, T., Sinclair, J. H., et al. (2018). A virally encoded DeSUMOylase activity is required for cytomegalovirus reactivation from latency. Cell reports 24, 594-606. doi: 10. 1016/j.celrep.2018.06.048

Qian, Z., Xuan, B., Gualberto, N., and Yu, D. (2011). The human cytomegalovirus protein pUL38 suppresses endoplasmic reticulum stress-mediated cell death 
independently of its ability to induce mTORC1 activation. J. Virol. 85, 91039113. doi: 10.1128/jvi.00572-11

Ranneberg-Nilsen, T., Rollag, H., Slettebakk, R., Backe, P. H., Olsen, Ø, Luna, L., et al. (2012). The chromatin remodeling factor SMARCB1 forms a complex with human cytomegalovirus proteins UL114 and UL44. PLoS One 7:e34119. doi: 10.1371/journal.pone.0034119

Razonable, R. R. (2018). Drug-resistant cytomegalovirus: clinical implications of specific mutations. Curr. Opin. Organ Trans. 23, 388-394. doi: 10.1097/MOT. 0000000000000541

Rechter, S., Scott, G. M., Eickhoff, J., Zielke, K., Auerochs, S., Müller, R., et al. (2009). Cyclin-dependent kinases phosphorylate the cytomegalovirus RNA Export Protein pUL69 and modulate its nuclear localization and activity. J. Biol. Chem. 284, 8605-8613. doi: 10.1074/jbc.M805693200

Reeves, M. B., Breidenstein, A., and Compton, T. (2012). Human cytomegalovirus activation of ERK and myeloid cell leukemia-1 protein correlates with survival of latently infected cells. Proc. Natl. Acad. Sci. U.S.A. 109, 588-593. doi: 10.1073/ pnas. 1114966108

Reeves, M. B., and Compton, T. (2011). Inhibition of inflammatory interleukin6 activity via extracellular signal-regulated kinase-mitogen-activated protein kinase signaling antagonizes human cytomegalovirus reactivation from dendritic cells. J. Virol. 85, 12750-12758. doi: 10.1128/JVI.05878-11

Reeves, M. B., Lehner, P. J., Sissons, J. G. P., and Sinclair, J. H. (2005). An in vitro model for the regulation of human cytomegalovirus latency and reactivation in dendritic cells by chromatin remodelling. J. Gen. Virol. 86(Pt 11), 2949-2954. doi: 10.1099/vir.0.81161-0

Revello, M. G., and Gerna, G. (2010). Human cytomegalovirus tropism for endothelial/epithelial cells: scientific background and clinical implications. Rev. Med. Virol. 20, 136-155. doi: 10.1002/rmv.645

Rodríguez-Sánchez, I., Schafer, X. L., Monaghan, M., and Munger, J. (2019). The Human Cytomegalovirus UL38 protein drives mTOR-independent metabolic flux reprogramming by inhibiting TSC2. PLoS Pathog. 15:e1007569. doi: 10. 1371/journal.ppat.1007569

Ross, S. A., Novak, Z., Pati, S., Patro, R. K., Blumenthal, J., Danthuluri, V. R., et al. (2011). Mixed infection and strain diversity in congenital cytomegalovirus infection. J. Infect. Dis. 204, 1003-1007. doi: 10.1093/infdis/jir457

Rossetto, C. C., Tarrant-Elorza, M., and Pari, G. S. (2013). Cis and trans acting factors involved in human cytomegalovirus experimental and natural latent infection of CD14 (+) monocytes and CD34 (+) cells. PLoS Pathog. 9:e1003366. doi: 10.1371/journal.ppat.1003366

Roubalová, K., Strunecký, O., Zufanová, S., Procházka, B., and Vitek, A. (2010). [Genotyping of viral glycoprotein B $(\mathrm{gB})$ in hematopoietic stem cell transplant recipients with active cytomegalovirus infection: analysis of the impact of gB genotypes on the patients' outcome]. Epidemiol. Mikrobiol. Imunol. 59, 92-99.

Ryckman, B. J., Chase, M. C., and Johnson, D. C. (2008). HCMV gH/gL/UL128-131 interferes with virus entry into epithelial cells: evidence for cell type-specific receptors. Proc. Natl. Acad. Sci. U.S.A. 105, 14118-14123. doi: 10.1073/pnas. 0804365105

Saffert, R. T., and Kalejta, R. F. (2006). Inactivating a cellular intrinsic immune defense mediated by Daxx is the mechanism through which the human cytomegalovirus pp71 protein stimulates viral immediate-early gene expression. J. Virol. 80, 3863-3871. doi: 10.1128/jvi.80.8.3863-3871.2006

Saffert, R. T., and Kalejta, R. F. (2007). Human cytomegalovirus gene expression is silenced by Daxx-mediated intrinsic immune defense in model latent infections established in vitro. J. Virol. 81, 9109-9120. doi: 10.1128/jvi.00827-07

Salsman, J., Wang, X., and Frappier, L. (2011). Nuclear body formation and PML body remodeling by the human cytomegalovirus protein UL35. Virology 414, 119-129. doi: 10.1016/j.virol.2011.03.013

Sampaio, K. L., Cavignac, Y., Stierhof, Y. D., and Sinzger, C. (2005). Human cytomegalovirus labeled with green fluorescent protein for live analysis of intracellular particle movements. J. Virol. 79, 2754-2767. doi: 10.1128/jvi.79.5. 2754-2767.2005

Sanchez, V., Greis, K. D., Sztul, E., and Britt, W. J. (2000). Accumulation of virion tegument and envelope proteins in a stable cytoplasmic compartment during human cytomegalovirus replication: characterization of a potential site of virus assembly. J. Virol. 74, 975-986. doi: 10.1128/jvi.74.2.975-986.2000

Sarisky, R. T., and Hayward, G. S. (1996). Evidence that the UL84 gene product of human cytomegalovirus is essential for promoting oriLyt-dependent DNA replication and formation of replication compartments in cotransfection assays. J. Virol. 70, 7398-7413. doi: 10.1128/jvi.70.11.7398-7413.1996

Sauer, C., Klobuch, S., Herr, W., Thomas, S., and Plachter, B. (2013). Subviral dense bodies of human cytomegalovirus stimulate maturation and activation of monocyte-derived immature dendritic cells. J. Virol. 87, 11287-11291. doi: 10.1128/JVI.01429-13

Schauflinger, M., Fischer, D., Schreiber, A., Chevillotte, M., Walther, P., Mertens, T., et al. (2011). The tegument protein UL71 of human cytomegalovirus is involved in late envelopment and affects multivesicular bodies. J. Virol. 85, 3821-3832. doi: 10.1128/JVI.01540-10

Schierling, K., Buser, C., Mertens, T., and Winkler, M. (2005). Human cytomegalovirus tegument protein ppUL35 is important for viral replication and particle formation. J. Virol. 79, 3084-3096. doi: 10.1128/jvi.79.5.3084-3096. 2005

Schommartz, T., Tang, J., Brost, R., and Brune, W. (2017). Differential requirement of human Cytomegalovirus UL112-113 protein isoforms for viral replication. J. Virol. 91:e00254-17. doi: 10.1128/jvi.00254-17

Seo, J. Y., and Britt, W. J. (2007). Cytoplasmic envelopment of human cytomegalovirus requires the postlocalization function of tegument protein pp28 within the assembly compartment. J. Virol. 81, 6536-6547. doi: 10.1128/ jvi.02852-06

Seo, J. Y., and Britt, W. J. (2008). Multimerization of tegument protein pp28 within the assembly compartment is required for cytoplasmic envelopment of human cytomegalovirus. J. Virol. 82, 6272-6287. doi: 10.1128/jvi.02345-07

Sharma, M., Bender, B. J., Kamil, J. P., Lye, M. F., Pesola, J. M., Reim, N. I., et al. (2015). Human cytomegalovirus UL97 phosphorylates the viral nuclear egress complex. J. Virol. 89, 523-534. doi: 10.1128/jvi.02426-14

Sharma, M., Kamil, J. P., Coughlin, M., Reim, N. I., and Coen, D. M. (2014). Human cytomegalovirus UL50 and UL53 recruit viral protein kinase UL97, not protein kinase $\mathrm{C}$, for disruption of nuclear lamina and nuclear egress in infected cells. J. Virol. 88, 249-262. doi: 10.1128/jvi.02358-13

Shen, S., Wang, S., Britt, W. J., and Lu, S. (2007). DNA vaccines expressing glycoprotein complex II antigens $\mathrm{gM}$ and $\mathrm{gN}$ elicited neutralizing antibodies against multiple human cytomegalovirus (HCMV) isolates. Vaccine 25, 33193327. doi: 10.1016/j.vaccine.2007.01.011

Shepp, D. H., Match, M. E., Ashraf, A. B., Lipson, S. M., Millan, C., and Pergolizzi, R. (1996). Cytomegalovirus glycoprotein B groups associated with retinitis in AIDS. J. Infect. Dis. 174, 184-187. doi: 10.1093/infdis/174.1.184

Shikhagaie, M., Mercé-Maldonado, E., Isern, E., Muntasell, A., Albà, M. M., LópezBotet, M., et al. (2012). The human cytomegalovirus-specific UL1 gene encodes a late-phase glycoprotein incorporated in the virion envelope. J. Virol. 86, 4091-4101. doi: 10.1128/JVI.06291-11

Shimamura, M., Mach, M., and Britt, W. J. (2006). Human cytomegalovirus infection elicits a glycoprotein $\mathrm{M}(\mathrm{gM}) / \mathrm{gN}$-specific virus-neutralizing antibody response. J. Virol. 80, 4591-4600. doi: 10.1128/jvi.80.9.4591-4600.2006

Shin, M. C., Hong, S. K., Yoon, J. S., Park, S. S., Lee, S. G., Lee, D. G., et al. (2006). Inhibition of UL54 and UL97 genes of human cytomegalovirus by RNA interference. Acta Virol. 50, 263-268.

Shnayder, M., Nachshon, A., Krishna, B., Poole, E., Boshkov, A., Binyamin, A., et al. (2018). Defining the transcriptional landscape during cytomegalovirus latency with single-Cell RNA sequencing. mBio 9:e00013-18. doi: 10.1128/mBio.00 013-18

Sijmons, S., Van Ranst, M., and Maes, P. (2014). Genomic and functional characteristics of human cytomegalovirus revealed by next-generation sequencing. Viruses 6, 1049-1072. doi: 10.3390/v6031049

Silva, M. C., Yu, Q. C., Enquist, L., and Shenk, T. (2003). Human cytomegalovirus UL99-encoded pp28 is required for the cytoplasmic envelopment of tegumentassociated capsids. J. Virol. 77, 10594-10605. doi: 10.1128/jvi.77.19.1059410605.2003

Sindre, H., Rollag, H., Olafsen, M. K., Degré, M., and Hestdal, K. (2000). Human cytomegalovirus induces apoptosis in the hematopoietic cell line MO7e. APMIS 108, 223-230. doi: 10.1034/j.1600-0463.2000.d01-48.x

Sinigalia, E., Alvisi, G., Mercorelli, B., Coen, D. M., Pari, G. S., Jans, D. A., et al. (2008). Role of homodimerization of human cytomegalovirus DNA polymerase accessory protein UL44 in origin-dependent DNA replication in cells. J. Virol. 82, 12574-12579. doi: 10.1128/jvi.01193-08

Sinigalia, E., Alvisi, G., Segré, C. V., Mercorelli, B., Muratore, G., Winkler, M., et al. (2012). The human cytomegalovirus DNA polymerase processivity factor 
UL44 is modified by SUMO in a DNA-dependent manner. PLoS One 7:e49630. doi: 10.1371/journal.pone.0049630

Skaletskaya, A., Bartle, L. M., Chittenden, T., McCormick, A. L., Mocarski, E. S., and Goldmacher, V. S. (2001). A cytomegalovirus-encoded inhibitor of apoptosis that suppresses caspase-8 activation. Proc. Natl. Acad. Sci. U.S.A. 98, 7829-7834. doi: 10.1073/pnas.141108798

Smith, L. R., Wloch, M. K., Chaplin, J. A., Gerber, M., and Rolland, A. P. (2013). Clinical development of a Cytomegalovirus DNA vaccine: from product concept to pivotal phase 3 trial. Vaccines 1, 398-414. doi: 10.3390/ vaccines 1040398

Smuda, C., Bogner, E., and Radsak, K. (1997). The human cytomegalovirus glycoprotein B gene (ORF UL55) is expressed early in the infectious cycle. J. Gen. Virol. 78(Pt 8), 1981-1992. doi: 10.1099/0022-1317-78-8-1981

Spaderna, S., Kropff, B., Ködel, Y., Shen, S., Coley, S., Lu, S., et al. (2005). Deletion of gpUL132, a structural component of human cytomegalovirus, results in impaired virus replication in fibroblasts. J. Virol. 79, 11837-11847. doi: 10.1128/ jvi.79.18.11837-11847.2005

Spector, D. J., and Tevethia, M. J. (1994). Protein-protein interactions between human cytomegalovirus IE2-580aa and pUL84 in lytically infected cells. J. Virol. $68,7549-7553$.

Spiess, K., Jeppesen, M. G., Malmgaard-Clausen, M., Krzywkowski, K., Dulal, K., Cheng, T., et al. (2015). Rationally designed chemokine-based toxin targeting the viral G protein-coupled receptor US28 potently inhibits cytomegalovirus infection in vivo. Proc. Natl. Acad. Sci. U.S.A. 112, 8427-8432. doi: 10.1073/ pnas. 1509392112

Stamminger, T., Gstaiger, M., Weinzierl, K., Lorz, K., Winkler, M., and Schaffner, W. (2002). Open reading frame UL26 of human cytomegalovirus encodes a novel tegument protein that contains a strong transcriptional activation domain. J. Virol. 76, 4836-4847. doi: 10.1128/jvi.76.10.4836-4847.2002

Stangherlin, L. M., de Paula, F. N., Icimoto, M. Y., Ruiz, L. G. P., Nogueira, M. L., Braz, A. S. K., et al. (2017). Positively selected sites at HCMV gB furin processing region and their effects in cleavage efficiency. Front. Microbiol. 8:934. doi: 10.3389/fmicb.2017.00934

Stanton, R. J., Baluchova, K., Dargan, D. J., Cunningham, C., Sheehy, O., Seirafian, S., et al. (2010). Reconstruction of the complete human cytomegalovirus genome in a BAC reveals RL13 to be a potent inhibitor of replication. J. Clin. Invest. 120, 3191-3208. doi: 10.1172/JCI42955

Strang, B. L., Boulant, S., and Coen, D. M. (2010a). Nucleolin associates with the human cytomegalovirus DNA polymerase accessory subunit UL44 and is necessary for efficient viral replication. J. Virol. 84, 1771-1784. doi: 10.1128/jvi. 01510-09

Strang, B. L., Geballe, A. P., and Coen, D. M. (2010b). Association of human cytomegalovirus proteins IRS1 and TRS1 with the viral DNA polymerase accessory subunit UL44. J. Gen. Virol. 91(Pt 9), 2167-2175. doi: 10.1099/vir.0. 022640-0

Straschewski, S., Patrone, M., Walther, P., Gallina, A., Mertens, T., and Frascaroli, G. (2011). Protein pUL128 of human cytomegalovirus is necessary for monocyte infection and blocking of migration. J. Virol. 85, 5150-5158. doi: 10.1128/JVI.02100-10

Sun, Y., Bao, Q., Xuan, B., Xu, W., Pan, D., Li, Q., et al. (2018). Human Cytomegalovirus Protein pUL38 prevents premature cell death by binding to ubiquitin-specific protease 24 and regulating iron metabolism. J. Virol. 92:e00191-18. doi: 10.1128/jvi.00191-18

Tabata, T., Petitt, M., Fang-Hoover, J., Freed, D. C., Li, F., An, Z., et al. (2019). Neutralizing monoclonal antibodies reduce human cytomegalovirus infection and spread in developing placentas. Vaccines 7:135. doi: 10.3390/ vaccines 7040135

Tadagaki, K., Tudor, D., Gbahou, F., Tschische, P., Waldhoer, M., Bomsel, M., et al. (2012). Human cytomegalovirus-encoded UL33 and UL78 heteromerize with host CCR5 and CXCR4 impairing their HIV coreceptor activity. Blood 119, 4908-4918. doi: 10.1182/blood-2011-08-372516

Tandon, R., and Mocarski, E. S. (2008). Control of cytoplasmic maturation events by cytomegalovirus tegument protein pp150. J. Virol. 82, 9433-9444. doi: 10. 1128/jvi.00533-08

Tandon, R., and Mocarski, E. S. (2011). Cytomegalovirus pUL96 is critical for the stability of pp150-associated nucleocapsids. J. Virol. 85, 7129-7141. doi: 10.1128/JVI.02549-10
Tang, J., Frascaroli, G., Lebbink, R. J., Ostermann, E., and Brune, W. (2019). Human cytomegalovirus glycoprotein B variants affect viral entry, cell fusion, and genome stability. Proc. Natl. Acad. Sci. U.S.A. 116, 18021-18030. doi: 10. 1073/pnas. 1907447116

Tao, R., Xu, J., Gao, H. H., Zhao, W. T., and Shang, S. Q. (2014). Characteristics and functions of human cytomegalovirus UL128 gene/protein. Acta Virol. 58, 103-107. doi: 10.4149/av_2014_02_103

Tavalai, N., Papior, P., Rechter, S., Leis, M., and Stamminger, T. (2006). Evidence for a role of the cellular ND10 protein PML in mediating intrinsic immunity against human cytomegalovirus infections. J. Virol. 80, 8006-8018. doi: 10.1128/jvi. 00743-06

Terhune, S., Torigoi, E., Moorman, N., Silva, M., Qian, Z., Shenk, T., et al. (2007). Human cytomegalovirus UL38 protein blocks apoptosis. J. Virol. 81, 3109-3123. doi: 10.1128/jvi.02124-06

Terhune, S. S., Schröer, J., and Shenk, T. (2004). RNAs are packaged into human cytomegalovirus virions in proportion to their intracellular concentration. J. Virol. 78, 10390-10398. doi: 10.1128/jvi.78.19.10390-10398.2004

To, A., Bai, Y., Shen, A., Gong, H., Umamoto, S., Lu, S., et al. (2011). Yeast two hybrid analyses reveal novel binary interactions between human cytomegalovirus-encoded virion proteins. PLoS One 6:e17796. doi: 10.1371/ journal.pone.0017796

Tomasec, P., Wang, E. C., Davison, A. J., Vojtesek, B., Armstrong, M., Griffin, C., et al. (2005). Downregulation of natural killer cell-activating ligand CD155 by human cytomegalovirus UL141. Nat. Immunol. 6, 181-188. doi: 10.1038/ nil156

Torres, L., and Tang, Q. (2014). Immediate-Early (IE) gene regulation of cytomegalovirus: IE1- and pp71-mediated viral strategies against cellular defenses. Virol. Sin. 29, 343-352. doi: 10.1007/s12250-014-3532-9

Toth, Z., Lischka, P., and Stamminger, T. (2006). RNA-binding of the human cytomegalovirus transactivator protein UL69, mediated by arginine-rich motifs, is not required for nuclear export of unspliced RNA. Nucleic Acids Res. 34, 1237-1249. doi: 10.1093/nar/gkl007

Trgovcich, J., Cebulla, C., Zimmerman, P., and Sedmak, D. D. (2006). Human cytomegalovirus protein $\mathrm{pp} 71$ disrupts major histocompatibility complex class I cell surface expression. J. Virol. 80, 951-963. doi: 10.1128/jvi.80.2.951-963.2006

Tschische, P., Tadagaki, K., Kamal, M., Jockers, R., and Waldhoer, M. (2011). Heteromerization of human cytomegalovirus encoded chemokine receptors. Biochem. Pharmacol. 82, 610-619. doi: 10.1016/j.bcp.2011.06.009

Tu, C. C., Arnolds, K. L., O'Connor, C. M., and Spencer, J. V. (2018). Human Cytomegalovirus UL111A and US27 Gene Products Enhance the CXCL12/CXCR4 Signaling Axis via Distinct Mechanisms. J. Virol. 92:e0198117. doi: 10.1128/JVI.01981-17

Tullman, J. A., Harmon, M. E., Delannoy, M., and Gibson, W. (2014). Recovery of an HMWP/hmwBP (pUL48/pUL47) complex from virions of human cytomegalovirus: subunit interactions, oligomer composition, and deubiquitylase activity. J. Virol. 88, 8256-8267. doi: 10.1128/jvi.00971-14

Tunnicliffe, R. B., Collins, R. F., Ruiz Nivia, H. D., Sandri-Goldin, R. M., and Golovanov, A. P. (2018). The ICP27 homology domain of the human cytomegalovirus protein UL69 adopts a dimer-of-dimers structure. mBio 9:e1112-18. doi: 10.1128/mBio.01112-18

van Senten, J. R., Bebelman, M. P., Fan, T. S., Heukers, R., Bergkamp, N. D., van Gasselt, P., et al. (2019). The human cytomegalovirus-encoded G proteincoupled receptor UL33 exhibits oncomodulatory properties. J. Biol. Chem. 294, 16297-16308. doi: 10.1074/jbc.RA119.007796

Varnum, S. M., Streblow, D. N., Monroe, M. E., Smith, P., Auberry, K. J., Pasa-Tolic, L., et al. (2004). Identification of proteins in human cytomegalovirus (HCMV) particles: the HCMV proteome. J. Virol. 78, 10960-10966. doi: 10.1128/jvi.78. 20.10960-10966.2004

Vey, M., Schäfer, W., Reis, B., Ohuchi, R., Britt, W., Garten, W., et al. (1995). Proteolytic processing of human cytomegalovirus glycoprotein B (gpUL55) is mediated by the human endoprotease furin. Virology 206, 746-749. doi: 10.1016/s0042-6822(95)80002-6

Vincenti, F., Budde, K., Merville, P., Shihab, F., Ram Peddi, V., Shah, M., et al. (2018). A randomized, phase 2 study of ASP0113, a DNA-based vaccine, for the prevention of CMV in CMV-seronegative kidney transplant recipients receiving a kidney from a CMV-seropositive donor. Am. J. Transpl. 18, 29452954. doi: $10.1111 /$ ajt.14925 
Wang, D., Li, G., Schauflinger, M., Nguyen, C. C., Hall, E. D., Yurochko, A. D., et al. (2013). The ULb' region of the human cytomegalovirus genome confers an increased requirement for the viral protein kinase UL97. J. Virol. 87, 6359-6376. doi: 10.1128/jvi.03477-12

Wang, D., and Shenk, T. (2005). Human cytomegalovirus virion protein complex required for epithelial and endothelial cell tropism. Proc. Natl. Acad. Sci. U.S.A. 102, 18153-18158. doi: 10.1073/pnas.0509201102

Wang, S.-K., Duh, C.-Y., and Wu, C.-W. (2004). Human cytomegalovirus UL76 encodes a novel virion-associated protein that is able to inhibit viral replication. J. Virol. 78, 9750-9762. doi: 10.1128/jvi.78.18.9750-9762.2004

Weekes, M. P., Tomasec, P., Huttlin, E. L., Fielding, C. A., Nusinow, D., Stanton, R. J., et al. (2014). Quantitative temporal viromics: an approach to investigate host-pathogen interaction. Cell 157, 1460-1472. doi: 10.1016/j.cell.2014.04.028

Weiland, K. L., Oien, N. L., Homa, F., and Wathen, M. W. (1994). Functional analysis of human cytomegalovirus polymerase accessory protein. Virus Res. 34, 191-206. doi: 10.1016/0168-1702(94)90124-4

Weisbach, H., Schablowsky, C., Vetter, B., Gruska, I., Hagemeier, C., and Wiebusch, L. (2017). Synthetic lethal mutations in the cyclin A interface of human cytomegalovirus. PLoS Pathog. 13:e1006193. doi: 10.1371/journal.ppat.1006193

Wilkinson, G. W., Davison, A. J., Tomasec, P., Fielding, C. A., Aicheler, R., Murrell, I., et al. (2015). Human cytomegalovirus: taking the strain. Med. Microbiol. Immunol. 204, 273-284. doi: 10.1007/s00430-015-0411-4

Wing, B. A., and Huang, E. S. (1995). Analysis and mapping of a family of 3'-coterminal transcripts containing coding sequences for human cytomegalovirus open reading frames UL93 through UL99. J. Virol. 69, 1521-1531. doi: 10.1128/jvi.69.3.1521-1531.1995

Winkler, M., Rice, S. A., and Stamminger, T. (1994). UL69 of human cytomegalovirus, an open reading frame with homology to ICP27 of herpes simplex virus, encodes a transactivator of gene expression. J. Virol. 68, 39433954. doi: 10.1128/jvi.68.6.3943-3954.1994

Woodhall, D. L., Groves, I. J., Reeves, M. B., Wilkinson, G., and Sinclair, J. H. (2006). Human Daxx-mediated repression of human cytomegalovirus gene expression correlates with a repressive chromatin structure around the major immediate early promoter. J. Biol. Chem. 281, 37652-37660. doi: 10.1074/jbc. m604273200

Xi, H., Jinjie, L., Shengxiang, G., Tingdong, L., Han, W., Xiaoyi, G., et al. (2017). Establishment and validation of an enzyme-linked immunosorbent assay for IgG antibody against cytomegalovirus based on pp150 antigen. J. Virol. Methods 240, 21-25. doi: 10.1016/j.jviromet.2016.11.001

Xu, Y., Cei, S. A., Rodriguez Huete, A., Colletti, K. S., and Pari, G. S. (2004). Human cytomegalovirus DNA replication requires transcriptional activation via an IE2and UL84-responsive bidirectional promoter element within oriLyt. J. Virol. 78, 11664-11677. doi: 10.1128/jvi.78.21.11664-11677.2004

Xuan, B., Qian, Z., Torigoi, E., and Yu, D. (2009). Human cytomegalovirus protein pUL38 induces ATF4 expression, inhibits persistent JNK phosphorylation, and suppresses endoplasmic reticulum stress-induced cell death. J. Virol. 83, 3463-3474. doi: 10.1128/jvi.02307-08

Yao, J.-X., Cui, G.-H., Xia, L.-H., and Song, S.-J. (2004). [In vitro infection of human megakaryocyte precursors by human cytomegalovirus (HCMV) and the antiviral effect of HCMV antisense oligonucleotides]. Zhonghua Xue Ye Xue Za Zhi = Zhonghua xueyexue zazhi 25, 720-723.

Yu, X., Jih, J., Jiang, J., and Zhou, Z. H. (2017). Atomic structure of the human cytomegalovirus capsid with its securing tegument layer of pp150. Science 356:eaam6892. doi: 10.1126/science.aam6892
Yurochko, A. D., and Huang, E. S. (1999). Human cytomegalovirus binding to human monocytes induces immunoregulatory gene expression. J. Immunol. 162, 4806-4816.

Yurochko, A. D., Hwang, E. S., Rasmussen, L., Keay, S., Pereira, L., and Huang, E. S. (1997). The human cytomegalovirus UL55 (gB) and UL75 (gH) glycoprotein ligands initiate the rapid activation of Spl and NF-kappaB during infection. J. Virol. 71, 5051-5059. doi: 10.1128/jvi.71.7.5051-5059.1997

Zarrouk, K., Piret, J., and Boivin, G. (2017). Herpesvirus DNA polymerases: structures, functions and inhibitors. Virus Res. 234, 177-192. doi: 10.1016/j. virusres.2017.01.019

Zhao, X.-Y., Luo, X.-Y., Yu, X.-X., Zhao, X.-S., Han, T.-T., Chang, Y.-J., et al. (2017). Recipient-donor KIR ligand matching prevents CMV reactivation posthaploidentical T cell-replete transplantation. Br. J. Haematol. 177, 766-781. doi: 10.1111/bjh.14622

Zhu, D., Pan, C., Sheng, J., Liang, H., Bian, Z., Liu, Y., et al. (2018). Human cytomegalovirus reprogrammes haematopoietic progenitor cells into immunosuppressive monocytes to achieve latency. Nat. Microbiol. 3, 503-513. doi: 10.1038/s41564-018-0131-9

Ziehr, B., Vincent, H. A., and Moorman, N. J. (2016). Human cytomegalovirus pTRS1 and pIRS1 antagonize protein kinase $\mathrm{R}$ to facilitate virus replication. J. Virol. 90, 3839-3848. doi: 10.1128/jvi.02714-15

Zielke, B., Thomas, M., Giede-Jeppe, A., Müller, R., and Stamminger, T. (2011). Characterization of the betaherpesviral pUL69 protein family reveals binding of the cellular mRNA export factor UAP56 as a prerequisite for stimulation of nuclear mRNA export and for efficient viral replication. J. Virol. 85, 1804-1819. doi: 10.1128/jvi.01347-10

Zimmermann, C., Büscher, N., Krauter, S., Krämer, N., Wolfrum, U., Sehn, E., et al. (2018). The abundant tegument protein pUL25 of human cytomegalovirus prevents proteasomal degradation of pUL26 and supports its suppression of ISGylation. J. Virol. 92:e01180-18. doi: 10.1128/jvi.01180-18

Zipeto, D., Hong, C., Gerna, G., Zavattoni, M., Katzenstein, D., Merigan, T. C., et al. (1998). Geographic and demographic differences in the frequency of human cytomegalovirus gB genotypes 1-4 in immunocompromised patients. AIDS Res. Hum. Retroviruses 14, 533-536. doi: 10.1089/aid.1998.14.533

Zuhair, M., Smit, G. S. A., Wallis, G., Jabbar, F., Smith, C., Devleesschauwer, B., et al. (2019). Estimation of the worldwide seroprevalence of cytomegalovirus: a systematic review and meta-analysis. Rev. Med. Virol. 29:e2034. doi: 10.1002/ rmv.2034

Zydek, M., Uecker, R., Tavalai, N., Stamminger, T., Hagemeier, C., and Wiebusch, L. (2011). General blockade of human cytomegalovirus immediate-early mRNA expression in the S/G2 phase by a nuclear, Daxx- and PML-independent mechanism. J. Gen. Virol. 92(Pt 12), 2757-2769. doi: 10.1099/vir.0.03 4173-0

Conflict of Interest: The authors declare that the research was conducted in the absence of any commercial or financial relationships that could be construed as a potential conflict of interest.

Copyright (c) 2020 Wang and Zhao. This is an open-access article distributed under the terms of the Creative Commons Attribution License (CC BY). The use, distribution or reproduction in other forums is permitted, provided the original author(s) and the copyright owner(s) are credited and that the original publication in this journal is cited, in accordance with accepted academic practice. No use, distribution or reproduction is permitted which does not comply with these terms. 